This is an electronic reprint of the original article. This reprint may differ from the original in pagination and typographic detail.

Author(s): Ruggiero, Salvatore; Lehkonen, Heikki

Title: $\quad$ Renewable energy growth and the financial performance of electric utilities : A panel data study

Year: $\quad 2017$

Version:

Please cite the original version:

Ruggiero, S., \& Lehkonen, H. (2017). Renewable energy growth and the financial performance of electric utilities : A panel data study. Journal of Cleaner Production, 142(Part 4), 3676-3688. https://doi.org/10.1016/j.jclepro.2016.10.100

All material supplied via JYX is protected by copyright and other intellectual property rights, and duplication or sale of all or part of any of the repository collections is not permitted, except that material may be duplicated by you for your research use or educational purposes in electronic or print form. You must obtain permission for any other use. Electronic or print copies may not be offered, whether for sale or otherwise to anyone who is not an authorised user. 


\section{Accepted Manuscript}

Renewable energy growth and the financial performance of electric utilities: A panel data study

Salvatore Ruggiero, Heikki Lehkonen

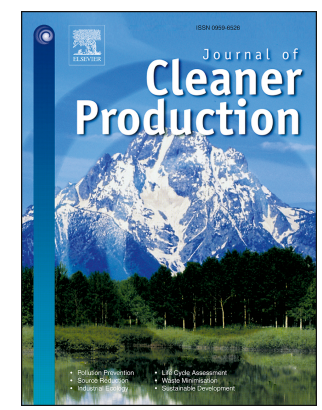

PII:

S0959-6526(16)31720-6

DOI:

10.1016/j.jclepro.2016.10.100

Reference: JCLP 8291

To appear in: Journal of Cleaner Production

Received Date: 22 June 2016

Revised Date: 22 September 2016

Accepted Date: 20 October 2016

Please cite this article as: Ruggiero $\mathrm{S}$, Lehkonen $\mathrm{H}$, Renewable energy growth and the financial performance of electric utilities: A panel data study, Journal of Cleaner Production (2016), doi: 10.1016/ j.jclepro.2016.10.100.

This is a PDF file of an unedited manuscript that has been accepted for publication. As a service to our customers we are providing this early version of the manuscript. The manuscript will undergo copyediting, typesetting, and review of the resulting proof before it is published in its final form. Please note that during the production process errors may be discovered which could affect the content, and all legal disclaimers that apply to the journal pertain. 


\title{
Renewable energy growth and the financial performance of electric utilities: A panel data study
}

\author{
Salvatore Ruggiero $^{\mathrm{a}}$, Heikki Lehkonen ${ }^{\mathrm{b}}$ \\ ${ }^{a}$ School of Business and Economics, University of Jyväskylä, Ohjelmakaari 10, PO Box 35, \\ 40014, Jyväskylä, Finland \\ ${ }^{\mathrm{b}}$ School of Business and Economics, University of Jyväskylä, Ohjelmakaari 10, PO Box 35, \\ 40014, Jyväskylä, Finland
}

\begin{abstract}
Electric utilities are under pressure to increase clean energy production. Although the adoption of renewable energy can improve the utilities' environmental performance, a fundamental question is if it also pays in economic terms. Building on the natural-resource-based view of the firm, we answer this question using two data analysis methods. First, we carry out a regression analysis of panel data from 66 large electric utilities covering the period 2005-2014, applying both a fixed and random effects estimator. Subsequently, we use the Granger causality test to explore possible causality links. Our results show a negative correlation at the firm level between renewable energy increase and short-term as well as long-term financial performance. More specifically, we find that an increase in renewable energy penetration Granger-causes a reduction of long-term performance. However, the results also show that a firm's carbon intensity moderates the relationship. When the focus is on the country level, we find that an increase in renewable power penetration is also negatively correlated to long-term firm performance, which might be explained by the combined effect of low power demand and overcapacity in developed economies. We conclude that the concept of organizational ambidexterity may supplement the natural-resource-based view of the firm for a better understanding of the relationship between an increase in renewable power and a firm's profitability.
\end{abstract}

Keywords: renewable energy, electric utilities, environmental performance, financial performance, natural-resource-based view of the firm 


\section{Introduction}

The Paris Agreement signed in 2015 may pave the way for a major transformation of the present energy provision system to renewable energy (IEA, 2016; UN, 2016). Electric utilities play a fundamental role in this process of change because they represent the backbone of the power supply infrastructure. However, even though the adoption of renewable energy can be seen as a way to improve environmental performance (EP), a fundamental question is if it also pays in economic terms. This is a timely question in light of the fact that, since 2011, large utilities have significantly reduced their capital expenditures on renewables (Frankfurt School-UNEP Centre/BNEF, 2015).

The discussion about whether an increase in renewable energy capacity may affect the financial performance (FP) of electric utilities can be seen as a part of the broader debate about corporate environmentalism and its profitability. Indeed, despite more than two decades of research, the question of if it pays to be green is far from settled. A slight majority of the studies indicate a positive relationship between EP and FP whereas the rest show either a negative or a neutral relationship (Albertini, 2013). Authors supporting a natural-resource-based view (NRBV) of the firm have argued that firms can attain a competitive advantage or superior performance by implementing proactive environmental strategies (Hart, 1995). Such strategies lead to the development of capabilities that have implications for a firm's performance in terms of lower costs, improved reputation, and strategic alignment with ongoing changes in the business environment (Aragón-Correa and Sharma, 2003).

Much of the literature stemming from the NRBV has mainly explored the greening of firms and its impact on performance (Hart and Dowell, 2011). To date, however, there is still little research focusing on firms that adopt a so-called beyond-greening strategy. Beyond-greening strategies address sustainability and include the adoption of clean technology (Hart, 1997; 2007). But in the domain of clean technology, it is unclear if firms can maintain a competitive advantage (Hart and Dowell, 2011). Thus, the first contribution of this study is to test if the NRBV of firms, which supports a positive link between a proactive environmental strategy and a firm's performance, is also valid in the context of a clean technology such as renewable energy. 
Second, researchers have begun to suggest that rather than addressing the question in terms of whether it pays to be green, it would be more fruitful to shift the focus of the discussion to when, - i.e., under which circumstances - it may pay to be green (Bernicchi and King, 2007; DixonFowler et al., 2012; King and Lenox, 2001; Orsato, 2009). Previous research (Hart and Ahuja, 1996) has shown that the improvement of EP has a higher impact on FP for heavy polluters than it does for firms that pollute less. This implies that electric utilities with high carbon intensity should benefit more from an increase in renewable energy production than utilities with already very low carbon intensity. The second contribution of this paper is to further move the debate from if to when it might be fruitful for a firm to improve its EP by examining the role of carbon intensity as a moderator of the renewable energy-profitability relationship.

In order to fill the two gaps identified above, we first carried out regression analysis of an unbalanced panel of 66 large electric utilities over the period 2005-2014 to evaluate the correlation between an increase in renewable energy production and firm performance. Then we applied the Granger causality test to explore possible causality links. The research questions we addressed can be formulated as follows: Does an increase in renewable energy production lead to higher FP for electric utilities? Does a firm's carbon intensity moderate the relationship?

The rest of this article is organized as follows: in section 2 we present a summary of the main literature and the NRBV approach, in section 3 we briefly discuss the electric utilities context, in section 4 we illustrate our data and methods, and in section 5 we present the findings. In section 6 we discuss our results and draw some conclusions.

\section{Theoretical framework}

\subsection{A summary of the Does it pay to be green? literature}

Over the last two decades a number of studies have focused on the relationship between corporate EP and FP. The results of this research are contradictory. According to a meta-analysis carried out by Albertini (2013) that included 52 studies over a 35-year period, a slight majority of studies have shown that better EP is positively correlated to a firm's FP. Some 
of these studies include Sen et al. (2015), Clarkson et al. (2011), Zeng et al. (2010), Hart and Ahuja, (1996), Wagner and Schaltegger (2004), King and Lenox (2001), Konar and Cohen (2001) and Russo and Fouts (1997). On the other hand, an almost equal number of papers have found that the relationship is neutral, or perhaps even negative (e.g., Cohen et al., 1997; Cordeiro and Sarkis, 1997; Filberck and Gorman, 2004; Graves and Waddock, 1999; Hassel et al., 2005; Morris, 1997; Sueyoshi and Goto, 2009; Telle, 2006).

Early research in the field was dominated by the traditional economic trade-off view, according to which enhancing EP implies extra costs for a firm, costs that in turn might hurt its FP. Thus, companies need to make a trade-off between acting to reduce their environmental burden and maintaining good FP. Some authors who have brought forth this view include Haveman and Christainsen (1981), Jaggi and Freedman (1992), Walley and Whitehead (1994), Portney (1994), Levy (1995) and Palmer et al. (1995). Later, the view that better EP can instead create opportunities for both increased revenues and lower costs has been proposed. Some of the most notable supporters of this second view are Porter and van der Linde (1995), Hart $(1995,1997)$ and Reinhardt (1999). They have indicated that increased revenues can stem from better access to certain markets, product differentiation and selling clean technology whereas lower costs may be achieved through better relationships with external stakeholders (Ambec and Lanoie, 2008). In addition, Aragon-Correa (1998) and Hart (1995) have suggested that EP improvements may also lead to strong organizational and management capabilities and enhance a firm's legitimacy.

An important set of studies within the large body of literature summarized above has also focused on the direction of the relationship between EP and FP. For instance, Earnhart and Lizal (2006), Dooley and Lerner (1994) and McGuire et al. (1988) have posited that, instead of EP acting on FP, it might be that FP influences EP. Companies with a good FP may have a surplus of financial resources, called "slack resources" by Waddock and Graves (1997), which they can invest to improve their EP when external pressure increases. However, research has also shown that slack resources can correlate differently with FP according to the type of industry (Miller et al., 1996). 
Along with the proponents of a link between FP and EP, the literature also contains studies that suggest a bidirectional relationship between the two variables. Some examples include the extensively cited work of Hart and Ahuja (1996) and more recent papers such as those of Makni et al. (2009), Surroca et al. (2010) or Carrion and Innes (2010). According to these authors companies with slack resources tend to improve their EP, which in turn increases FP that again can lead to further improvements of EP. In other words, the relationship between EP and FP would move from the first to the second and from the second to the first, creating what Hart and Ahuja (1996, p. 36) have called a "virtuous circle".

Because research about the relationship between EP and FP has led to contrasting results, some authors have concentrated on methodological issues in studying the relationships between the two variables. Three main methodological approaches have been employed to explore the EP-FP relationship: (a) portfolio analyses, (b) event studies and (c) long-term studies using regression analysis (Ambec and Lanoie, 2008). The first method consists of comparing the economic performance of portfolios that include companies with high EP against those including companies with no environmental features. The main limit of these studies is the fact that FP depends heavily on a firm's fund management ability. Event studies aim at investigating the effects of environmental events, generally negative, on areas such as stock market performance. Although this approach can identify a clear causal relationship in the days soon after the negative event, it is difficult to evaluate the specific effects of such an event over the long term. The last approach, the one used in this study, relies on regression analysis to investigate the relationship between various companies' characteristics over a certain period of time. Studies based on regression analysis may appear to be the most suitable ones for exploring the EP-EF link (Ambec and Lanoie, 2008), but they show a lack of consistency in operationalizing both the independent and dependent variable (i.e., EP and FP) and often overlook the important role of control variables (Telle, 2006). In the next section we discuss this lack of consistency in operationalizing EP and FP variables.

Finally, researchers have also explored the link between companies with different types of environmental strategies and their FP. One of the most important contributions in this context was the NRBV proposed by Hart (1996), which is discussed in more detail below. The main 
argument justifying this research strand is the fact that the link between the competitive advantage of the firm and the environmental strategy depends on the form of environmental improvement under consideration (Hart and Dowell, 2010).

\subsubsection{Lack of consistency in operationalizing EP and FP}

Bagaeva (2008) notes that most of the studies on the relationship between EP and FP have focused their analysis on a limited variety of industrial sectors such as pulp and paper (Jaggi and Freedman, 1992) or mining (Magness, 2006). Moreover, they take into account only specific indicators of environmental pollution (King and Lenox, 2001; Jung et al. 2001; Hughes, 2000; Hart and Ahuja, 1996) and do not distinguish between performance improvements attained by end-of-pipe solutions (addressing environmental pollution after it is produced) and those achieved through more proactive strategies (Ilinitch et al., 1998).

To a lesser extent, the lack of uniformity in the FP measures used has also been problematic. The most recurrent measures of FP found in the literature are return on assets (ROA), return on equity (ROE) and return on sales (ROS; e.g. Earnhart and Lizal, 2007). Along with these financial ratios, market-based measures such as market value, stock returns and Tobin's q have been employed (e.g., Dowell et al., 2000; Gilley et al., 2000; Khanna et al., 1998). Several scholars have pointed out that because financial ratios and market-based measures have a different focus they may lead to different results. For instance, financial ratios are effective indicators of a firm's ability to generate value from its assets in the short term, but they are not appropriate in measuring intangible and long-term benefits associated with a better EP (Orlitzky et al., 2003; Delmas and Nairn-Birch, 2010). As a result, market-based measures may give a more comprehensive picture of the long-term economic benefits associated with EP enhancements. Furthermore, financial ratios express a firm's efficiency in generating value by using its assets as well as the firm's internal capabilities and performance whereas market-based measures reflect the external perception of performance (Orlitzky et al., 2003).

\subsection{The natural-resource-based view approach}


The NRBV was developed to complement the pre-existing resource-based theory with the omitted environmental variable. One important insight of this approach is that resources help firms to develop capabilities that can, in turn, lead to competitive advantage. More specifically, Hart and Dowell (2010, p. 1466) argue that firms can gain competitive advantage by developing “capabilities that facilitate environmentally sustainable economic activity". In Hart's (1995) original work, three key strategic capabilities were described: pollution prevention, product stewardship, and sustainability. Each strategic capability can yield a different type of competitive advantage which can, in turn, have implications for performance (Aragón-Correa and Sharma, 2003). Pollution prevention focuses on waste minimization and can lead to increases in efficiency and cost reduction. Product stewardship, by extending pollution prevention to the full life cycle of a product, creates opportunities for firms to profit from differentiation. Sustainability, in comparison, leads to strategic alignment with emerging changes in the business environment (Aragón-Correa and Sharma, 2003).

In later research, Hart and Dowell (2011) have highlighted the role of clean technology in the sustainability category. They maintain that clean technology brings about disruptive change and requires strategies that go beyond the greening of the firm. Moreover, it involves ability in dealing with "areas of knowledge that are uncertain, constantly evolving, and dynamically complex" (Hart and Dowell, 2011, p. 1471). As a result, firms may not necessarily be able to achieve a competitive advantage in this domain.

Ultimately, Hart and Dowell (2010) have called for new research to test whether the NRBV's core proposition may also be applied in the context of high uncertainty and discontinuous change typically associated with the adoption of clean technologies. In this study, we answer this call by using the case of electric utilities to test if Hart's (1995) original argument is also valid in the domain of renewable energy.

\subsubsection{Moving from if it pays to when it pays to be green}

More recently, some authors have criticized the argument that firms with a proactive environmental strategy can have more advantages than firms with reactive strategies. For 
instance, Orsato (2009, p. 3) rightly observed: "If there are so many advantages for business, why is corporate proactive behavior not a widespread phenomenon? Why hasn't commerce yet led us to sustainable societies?" These scholars, therefore, suggest that research on the relationship between EP and FP may gain more consistency if the focus is shifted from the question "Does it pay to be green?" to the question of "When does it pay to be green?" Their view is supported by the argument that EP improvement may pay only under certain conditions, such as for firms that have certain attributes or that reduce pollution by certain means or in certain time frames (Dixon-Fowler et al., 2012; Orsato, 2009; Bernicchi and King, 2007; King and Lenox, 2001).

Recent empirical research has started to reveal some factors that can moderate the EP-FP link. For instance, Karagozoglu and Lindell (2000) found that supportive / less supportive regulation plays a fundamental role in determining whether the greening of a firm pays. Building on this, Stoeckl (2004) determined that firms benefit most from supportive regulations when they operate in highly competitive markets. Among internal factors that moderate the EP-FP link, Hart and Ahuja (1996) found that emission reduction initiatives had a higher impact on FP more for heavy polluters than for firms with an already lower level of emissions. In contrast, Aragon-Correra et al. (2008) demonstrate that a firm's size is another relevant factor in the EP-FP relationship.

After a review of the main literature, two main conclusions can be drawn. First, the discussion to date has mainly revolved around how the greening of the firm, sometimes seen in a proactive way and sometimes in a reactive one, can lead to better performance. However, very few authors have concentrated on what Hart (1997) calls a beyond-greening strategy, that is, those strategies that address sustainability. Second, consistent with Berchicci and King (2007), we feel that future research would benefit if the focus were to shift towards identifying the contingencies that affect the EP-FP relationship.

\section{Renewable energy and financial performance of electric utilities}

In this study we look at a specific aspect of utilities' EP: the adoption of renewable energy technology in electric power production. We focus on the electric utility industry for two 
reasons: (a) the industry owns a large share of the generation and distribution infrastructure, (b) the electricity and heat generation sector is by far the sector with the highest amount of $\mathrm{CO} 2$ emissions. According to IEA (2015), the sector accounts for $42 \%$ of global emissions.

Over the last two decades, the power sector has been privatized in numerous developed and developing countries (Bacon and Besant-Jones, 2001) though it remains highly regulated. The growth of renewable energy production in the industry has been mainly driven by policy mechanisms such as feed-in tariffs and renewable quota obligation / portfolio standards. (For a more in-depth review of these mechanisms, see, e.g., Menanteau et al., 2003). The first type of mechanism is a form of subsidy that guarantees a certain price over a long period of time. The second is a regulatory intervention of the government forcing electric utilities to produce a portion of their electricity from renewable energy sources (Verbruggen and Lauber, 2012).

Although these policy mechanisms, especially feed-in tariffs, have contributed to a wider diffusion of renewable energy in the sector, it is unclear if deeper levels of renewable energy penetration also lead to better FP for electric utilities. Research in this field to date has focused on the more general link between EP and the performance of electric industry firms. For instance, Pätäri et al. (2014) looked at the relationship between corporate social responsibility and FP, finding that corporate social responsibility is correlated to only market-based measures. Filbeck and Gorman (2004) concentrated on the link between companies with a more proactive environmental strategy and FP and found a negative relationship. Sueyoshi and Goto (2009) investigated whether environmental investment and expenditure enhance the FP of electric utilities in the United States. They established that there is no influence of environmental investment on FP.

Furthermore, according to Sueyoshi and Goto (2009), renewable energy production implies higher costs for utilities. These costs are triggered by three key factors. First, new linkages to the grid need to be built because sites with good renewable energy sources are often far from consumption areas. Second, the grid needs to be reinforced to accommodate fluctuating amounts of electricity. Third, plants using renewable energy sources have much higher capital costs than do conventional power plants relying on fossil fuels. Such factors, in combination with how the price of electricity in many countries is essentially regulated to safeguard consumers, can lead to 
a situation in which investment in renewable energy may not immediately improve the FP of electric utilities.

\section{Data and Methods}

\subsection{Sample}

To evaluate the relationship between the adoption of renewable energy and FP, we used an unbalanced panel of 66 electric utilities over the period 2005-2014. We acquired the data concerning firms' renewable energy production and FP from Thomson Reuters's DataStream (Thomson Reuters, 2016). We searched under the category "electricity" for utilities involved in electricity production and identified about 180 firms. Subsequently, we removed from the sample those firms that were only engaged in electricity distribution and kept firms that were also energy distributors but that mainly focused on generation. Other companies for whom we could not find financial data were also removed from the sample. The companies we eventually selected are from 26 different countries, with North America, the European Union and Eastern Asia as the three most important groups. Appendix A shows the number of firms from each country and region.

\subsection{Variables}

\subsubsection{Dependent variables}

In most previous studies financial ratios such as ROA, ROE and ROS have been used (Earnhart and Lizal, 2007). To a lesser extent market-based measures such as market capitalization, stock returns and Tobin's q have been employed (e.g., Päätäri et al. 2014, Dowell et al. 2000; Gilley et al., 2000; Khanna et al., 1998). Because some scholars (Orlitzky et al., 2003; Delmas and NairnBirch, 2010) have indicated that financial ratios may possibly not be able to capture the longterm FP of a firm, we used both accounting and market-based measures to increase the reliability of our analysis (Martin, 1993).

Thus, our dependent variables include ROE, ROA and Tobin's q. We measured ROE and ROA, respectively, as the ratio of net income to shareholder's equity and net income to total assets. In 
accordance with Lindenberg and Ross (1981), we calculated Tobin's q as the ratio of a firm's market value to the book value of its total assets. Tobin's q reflects reputational effects, investor trust and investor risk (Guensteret et al., 2005). In an equilibrium situation its value is 1 . A Tobin's q larger than 1 means that the market value of the firm is higher than the book value of its assets and, consequently, the company is overvalued. On the other hand, when the Tobin's q is smaller than 1 , the market value of the firm is smaller than the book value of its assets. This condition suggests that the market may be undervaluing the company.

\subsubsection{Independent and control variables}

Our main independent variable was the volume of renewable energy produced yearly (RE.VOLUME) expressed in gigajoules. Because several authors (e.g., Telle, 2006; Earnhart and Lízal, 2007; and Hart and Ahuja, 1996) have suggested that there is often a time lag between the initiation of emission reduction initiatives and the manifestation of the possible financial benefits, we also used four time-lag values of our main independent variable. In doing so, we separately analyzed both the concurrent effects of the increase in renewable energy production on FP as well as the possible delayed effects captured by the lagged variables RE.VOLUME lag1, lag2, lag3, and lag4.

In addition to our main independent variable, we included several control variables in our model that were identified through the review of the literature. They are firm size (SIZE), risk (RISK), capital intensity (CAPINT), firm growth (GROWTH), carbon intensity (CARBINT), and yearly time trend for the years 2005-2014 (TIME). In addition, we also used some control variables for the context of a firm. They include the level of renewable energy penetration (RE.PENETRATION) of the firm's home country as well as two dummies for evaluating differences between developed economies (DE) and emerging markets (EM).

Firm size has often been considered to be a determinant of EP and FP. This is connected to the previously discussed effect of slack resources (Waddock and Graves, 1997) that may create a double loop between EP and FP. Several proxies for firm size have been proposed, including the natural logarithm of the number of employees (Nishitani et al., 2012), sales (Pätäri et al., 2014) and total assets (Gallego-Álvarez et al., 2014; Sueyoshi and Goto, 2009; Wang et al., 2014; 
Elsayed and Paton, 2005). Because all of the firms in our panel were listed, we used the natural logarithm of market capitalization as a proxy for size. We expected this variable to be positively correlated to the FP variables.

Firm risk is another control variable often cited in the context of EP-FP studies. Firms that have a high level of commitment to environmental protection may be rewarded by the market because their investors may perceive lower risks associated with that company (Sharfman and Fernando, 2008). Some studies have used a firm's Beta as a proxy for risk. In line with Waddock and Graves (1997) and McWilliams and Siegel (2000), in this study we used leverage, expressed as the ratio of the total debt to total assets, to measure risk. We also expected this variable to be positive. Capital intensity increase has been associated with reduction of direct costs and thus is another frequently used control variable (Berman et al., 1999). Consistent with Wang et al. (2014), we measured capital intensity as capital expenditures divided by sales and use the natural logarithm. Previous literature (Russo and Fouts, 1997) has shown that the relationship between $\mathrm{EP}$ and FP is strengthened when the company is in a fast-growing industry. To control for firm growth rate, we used a firm's annual change in sales, expressed as a percentage.

Because one of our purposes was to determine whether there were differences for firms with high $\mathrm{CO} 2$ emissions in comparison to firms with low emissions, we tested if carbon intensity acted as a moderator. We derived this variable by dividing the amount (in tons of CO2e) of greenhouse gas emissions by the value of total assets expressed in USD. Based on Hart and Ahuja (1996), we expected that this variable, in interaction with the volume of renewable energy produced, would be positive.

To account for the effects of the contexts in which the studied electric utilities operate, we controlled for the level of renewable energy penetration in the firm's home market. We used the level of renewable electricity penetration as a proxy for both the growth of the sector and the level of policy support because renewable energy expansion is mainly policy driven. Consequently, we assumed that countries with high levels of renewable energy penetration probably also have strong policy support mechanisms which drive the growth of the sector. Finally, we created dummy variables to control for possible differences between developed 
economies and emerging markets. Table 1 presents a synthesis of how we defined and measured our variables. 
Table 1. Variables definition

\begin{tabular}{|l|l|l|l|}
\hline Variable name & Variable definition & $\begin{array}{l}\text { Transformation } \\
\text { applied }\end{array}$ & $\begin{array}{l}\text { Unit of } \\
\text { measure }\end{array}$ \\
\hline ROE & Return on equity calculated as net income divided by shareholder's equity & & \\
\hline ROA & Return on assets calculated as net income divided by total assets & & \\
\hline Tobin's q & $\begin{array}{l}\text { Tobin's q calculated as the market value of a firm as expressed by enterprise } \\
\text { value divided by book value of total assets }\end{array}$ & \\
\hline RE.VOLUME & Volume of renewable energy generated yearly & Natural logarithm & Gigajoules \\
\hline TIME & Yearly time trend for the period 2005-2013 & Natural logarithm & USD \\
\hline SIZE & Size of the firm in terms of market capitalization & & USD \\
\hline RISK & Ratio of total debt to total assets & Natural logarithm & USD \\
\hline CAP.INTEN & Ratio of capital expenditures to sales & & TWh \\
\hline GROWTH & Increase in percentage in sales on a yearly basis & $\begin{array}{l}\text { Tons } \\
\text { CO2e/USD }\end{array}$ \\
\hline RE.PENETRATION & Share of renewable power for a firm's home country calculated on a yearly basis & & \\
\hline CARBINT & Ratio of total amount of greenhouse gas emissions to total assets & & \\
\hline
\end{tabular}




\subsection{Regression model and estimation methods}

The analytical method we selected to answer our research question was linear regression for panel data. We applied both fixed effects (FE) and random effects (RE) estimation methods with the support of the statistical software package STATA, version 14. In addition, we used the Granger causality test to verify if, along with a correlation, there was also a causality link between EP and FP.

FE and RE effect methods have strengths and limitations. Considering a general linear regression panel model

$$
Y_{i t}=\beta_{0}+\beta X_{i t}+\gamma Z_{i}+\alpha_{i}+\varepsilon_{i t} \quad i=1,2, \ldots, N, \quad t=1,2, \ldots, T
$$

where

- $Y_{i t}$ is $\mathrm{s}$ the dependent variable observed for individual $i$ in time $t$,

- $\beta_{0}$ is the constant term,

- $X$ is the independent variables whose values can vary across time,

- $Z$ is the independent variables whose values do not change across time,

- $\beta$ and $\gamma$ are the coefficients for $X_{\mathrm{s}}$ and $Z_{\mathrm{s}}$,

- $\alpha_{i}$ the error term that varies only across individuals but not across time (heterogeneity),

- $\varepsilon_{i t}$ is the error term which assumes different values for each individual at each point in time,

the types of assumptions that are made about $\alpha_{\mathrm{i}}$ distinguish one model from the other. In other words, the distinction between the two models lies in whether the individual-specific timeinvariant effects, $\alpha_{\mathrm{i}}$, are correlated with the regressors or not. In an FE model $\alpha_{\mathrm{i}}$ is assumed to be correlated with $\mathrm{X}_{\mathrm{it}}$, but an RE model is uncorrelated. For FE models the two main estimators used are least squares dummy variable (LSDV) regression and the within effect estimation method whereas for the RE models they are GLS (generalized least squares) or FGLS (estimated generalized least squares). In this study we used the within-effect estimation method for the FE model and the GLS for the RE model. 
One of the main characteristics of the FE model is that it eliminates all the unobserved time invariant factors such as sex, race and religion as well as those contextual factors that change slowly over time (Baltagi, 2008). Therefore, an important limitation is the fact that it cannot assess the effect of variables that have little within-group variation, because it considers only within-individual differences, discarding any information about differences between individuals. This characteristic limits the risk of bias due to omitted variables, but it comes at the cost of higher standards errors (Allison, 2009). On the other hand, the RE model can estimate the impact of time invariant factors and has lower standard errors than the FE model does, but it does not control for possible omitted variables.

Another important difference stemming from the two different assumptions described above is connected with the type of inferences that can be made. In an FE model it is implicitly assumed that all the individuals in the sample are one of a kind and are not a random sample from a population at large (Verbeek, 2008). This is useful only if we want to make, for instance, predictions for a particular country, region or type of industry. On the contrary, RE estimation models assume a normal distribution, so we can make inferences to a larger population (Verbeek, 2008). To decide which of the two estimation models is the most appropriate, the Hausman test can be applied. In this study we kept both FE and RE models in order to show the variation of our findings under the different assumptions underlying the two models.

In addition to the level of correlation, we also wanted to investigate possible causal links between our focal variables. We studied this issue using a Granger causality test, in which a variable $\mathrm{X}$ is said to Granger-cause variable $\mathrm{Y}$ if the lagged values of $\mathrm{X}$ help to explain $\mathrm{Y}$ even though the past values of $Y$ have been taken into account. Thus, the changes in variable $X$ should precede the changes in $\mathrm{Y}$. In practice, Granger causality between $\mathrm{X}$ and $\mathrm{Y}$ can be tested with the following equations:

$$
\begin{aligned}
& Y_{i t}=\alpha_{0}+\sum_{j=1}^{n} \alpha_{j} Y_{i t-j}+\sum_{k=1}^{n} \beta_{k} X_{i t-k}+\varepsilon_{1 i t} \\
& X_{i t}=\gamma_{0}+\sum_{j=1}^{n} \gamma_{j} Y_{i t-j}+\sum_{k=1}^{n} \delta_{k} X_{i t-k}+\varepsilon_{2 i t}
\end{aligned}
$$


where the error terms are assumed to be uncorrelated. $\mathrm{X}$ is said to Granger-cause $\mathrm{Y}$ if its coefficients are statistically significantly different from zero jointly and vice versa for $\mathrm{Y}$. The alternatives are, therefore, that either $\mathrm{X}$ Granger-causes $\mathrm{Y}, \mathrm{Y}$ Granger-causes $\mathrm{X}$, they both Granger-cause each other or there is no relationship.

We followed the method used in Pätäri et al. (2014) and assumed that the coefficients of the explanatory variables were the same for all cross-sectional units (in our case, companies) and that there was no causal variation among the cross-sections. Instead of finding optimal lag lengths by using, for example, Akaike or Bayesian information criteria, we simply tested several alternative lag structures and examined whether there were any changes in the results for different lag lengths.

\section{Results}

\subsection{Descriptive Analysis}

Table 2 presents the descriptive statistics of the variables of interest. The second and third columns are the mean and standard deviation for each of the variables and the other columns show the correlation matrix. The average value of Tobin's q was 0.856 . Therefore, according to the typical interpretation of this market-based indicator, the companies in the study were, on average, undervalued. The total debt to assets ratio was about $38 \%$, the ratio of capital expenditure to sales was about $14.5 \%$, and average annual sales growth for the companies was about $8 \%$. The amount of renewable energy produced was a bit more than 19 million gigajoules per year.

In general, the unconditional pairwise correlations between the variables were rather small. As can be expected, the correlations between ROE, ROA and Tobin's q were some of the largest in the table. In addition, the amount of renewable energy generated was positively related (0.302) to firm size, suggesting that larger companies produced more renewable energy. The correlation between renewable energy and the carbon intensity (the ratio of produced carbon emissions to total assets) was negative but rather modest. Also, for the other pairs, the absolute value of correlation was below 0.3 , thus the multicollinearity was not a problem in our estimations. 
To complete our descriptive analysis and before proceeding with the regression models, we created three scatterplots to visually inspect the data (see Appendix B). As can be seen, all of the figures show a negative relationship between the volume of renewable energy and all of the performance measures.

Because we have a panel data sample, we also visualized how the average value of our dependent and key explanatory variables changed over time. Figure 1 clearly shows that the firm performance measures and the volume of renewable energy moved in completely opposite directions during almost the entire sample period. Only after 2013 did all the variables seem to increase in tandem.

Figure 1. Average change of renewable energy production ROE, ROA and Tobin's q over time ${ }^{1}$

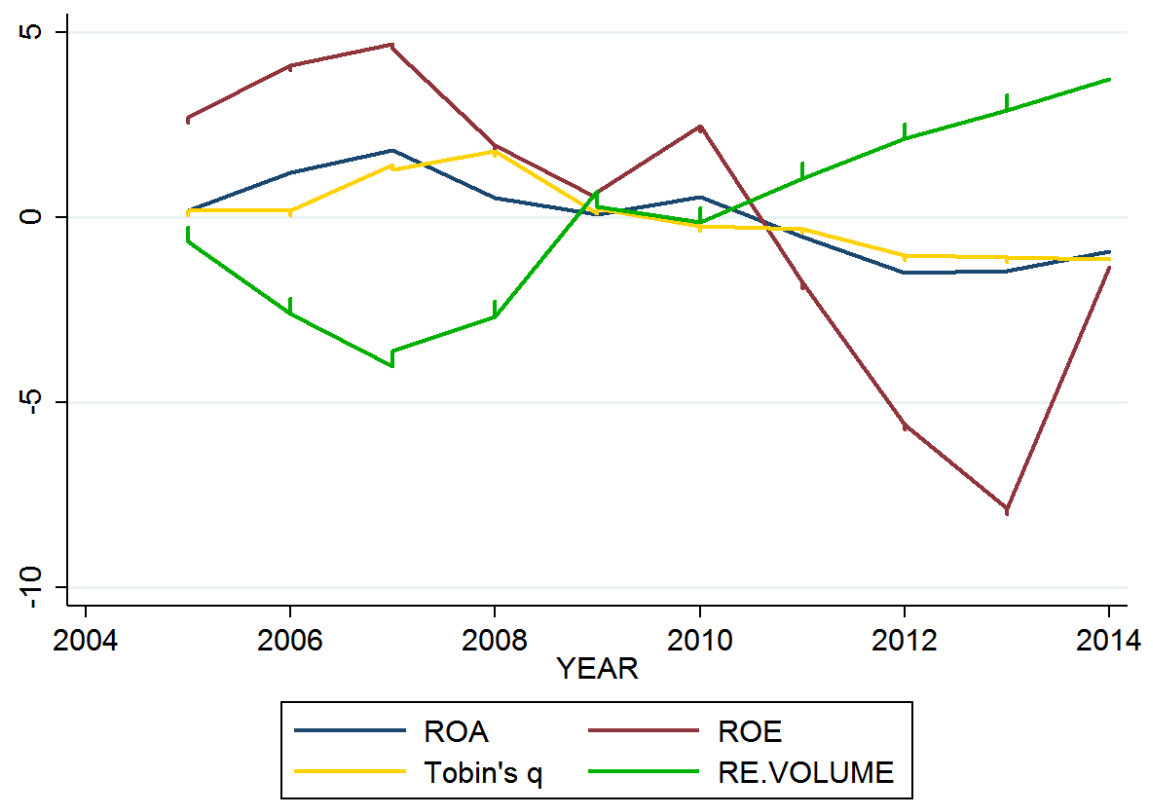

\footnotetext{
${ }^{1}$ In order to plot all of the time series in the same figure, we first scaled RE.VOLUME and Tobin's q by multiplying their values by 10 . We then calculated the cross-sectional yearly averages for the variables and demeaned those time series.
} 
Table 2. Descriptive statistics

\begin{tabular}{|c|c|c|c|c|c|c|c|c|c|c|c|c|c|}
\hline & $\mathrm{N}$ & Mean & Std. & ROE & $\mathrm{ROA}$ & Tobin's q & RE.VOLUME & SIZE & RISK & CAPINT & GROWTH & RE.PENETRATION & CARBINT \\
\hline $\mathrm{ROE}$ & 646 & 9.658 & 14.331 & 1 & & & & & & $y$ & & & \\
\hline $\mathrm{ROA}$ & 651 & 4.442 & 4.154 & 0.733 & 1 & & & & 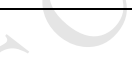 & & & & \\
\hline Tobin's q & 633 & 0.876 & 0.356 & 0.270 & 0.414 & 1 & & & 3 & & & & \\
\hline RE.VOLUME & 482 & 16.766 & 2.086 & -0.019 & -0.098 & -0.142 & 1 & & & & & & \\
\hline SIZE & 641 & 16.161 & 0.999 & 0.218 & 0.138 & 0.013 & 0.302 & 1 & & & & & \\
\hline RISK & 653 & 0.373 & 0.143 & -0.237 & -0.266 & 0.078 & 0.050 & -0.239 & 1 & & & & \\
\hline CAPINT & 649 & -1.926 & 0.767 & -0.064 & -0.015 & 0.152 & -0.091 & -0.015 & 0.019 & 1 & & & \\
\hline GROWTH & 647 & 0.183 & 2.025 & 0.002 & 0.024 & 0.186 & 0.092 & -0.015 & -0.037 & 0.213 & 1 & & \\
\hline RE.PENETRATION & 609 & 2.772 & 0.757 & 0.060 & 0.034 & 0.025 & 0.009 & -0.019 & 0.015 & 0.061 & 0.079 & 1 & \\
\hline CARBINT & 591 & 1.444 & 1.721 & -0.001 & 0.063 & 0.149 & -0.235 & -0.160 & 0.192 & 0.198 & -0.004 & -0.096 & 1 \\
\hline
\end{tabular}

Note: The table presents the mean values and standard deviations for the variables and simple unconditional pairwise correlations between them.

In total the unbalanced panel has 66 companies for the years 2005-2014. 


\subsection{Results of regression analysis}

For our estimation we required that all our variables were stationary. Thus, we started by testing the stationarity using the Fisher test and found that Tobin's q and SIZE were non-stationary ${ }^{2}$. However, when the trend term was included in the Fisher tests, both of these became stationary and thus for the final estimations both Tobin's q and SIZE were de-trended.

Subsequently, we analyzed the relationship between FP and renewable energy production. Table 3 reports the results from the panel data regressions. In order to add robustness, the results for both the FE models (odd columns) and the RE models (even columns) have been reported. In the first and second columns we used return on equity (ROE) as the dependent variable, in the third and fourth columns it was return on assets (ROA), and in the fifth and sixth columns it was Tobin's q. The columns for Tobin's q estimations present the long-term performance whereas the other measures (i.e., ROE and ROA) reflect short-term performance. Of the explanatory variables, our main interest lies in the volume of the generated renewable energy (RE.VOLUME).

Table 3. Renewable energy and firm performance

\begin{tabular}{|c|c|c|c|c|c|c|}
\hline VARIABLES & $\begin{array}{l}(\mathrm{FE}) \\
\mathrm{ROE} \\
\end{array}$ & $\begin{array}{l}\text { (RE) } \\
\text { ROE }\end{array}$ & $\begin{array}{l}(\mathrm{FE}) \\
\text { ROA } \\
\end{array}$ & $\begin{array}{l}\text { (RE) } \\
\text { ROA }\end{array}$ & $\begin{array}{c}(\mathrm{FE}) \\
\text { Tobin's q } \\
\end{array}$ & $\begin{array}{c}(\mathrm{RE}) \\
\text { Tobin's q } \\
\end{array}$ \\
\hline RE.VOLUME & $\begin{array}{c}-\mathbf{0 . 8 4 4} * \\
(0.491)\end{array}$ & $\begin{array}{l}-0.301 \\
(0.331)\end{array}$ & $\begin{array}{l}-\mathbf{0 . 1 7 4} * \\
(0.0996)\end{array}$ & $\begin{array}{l}-\mathbf{0 . 1 6 6 *} \\
(0.0860)\end{array}$ & $\begin{array}{c}-\mathbf{0 . 0 1 6 1} * * * \\
(0.00527)\end{array}$ & $\begin{array}{c}-\mathbf{0 . 0 1 2 5} * * \\
(0.00578)\end{array}$ \\
\hline SIZE & $\begin{array}{c}\text { 13.15**** } \\
(3.700)\end{array}$ & $\begin{array}{c}\mathbf{1 2 . 6 9} * * * * \\
(3.054)\end{array}$ & $\begin{array}{c}\mathbf{2 . 1 8 6} * * * * \\
(0.586)\end{array}$ & $\begin{array}{c}\mathbf{2 . 4 9 8}^{*} * * * \\
(0.465)\end{array}$ & $\begin{array}{c}\mathbf{0 . 2 5 2} * * * \\
(0.0459)\end{array}$ & $\begin{array}{c}\mathbf{0 . 2 6 4} * * * \\
(0.0478)\end{array}$ \\
\hline RISK & $\begin{array}{c}\mathbf{- 4 5 . 5 6} \text { *** } \\
(19.20)\end{array}$ & $\begin{array}{c}-\mathbf{2 6 . 5 8} * * * \\
(8.220)\end{array}$ & $\begin{array}{c}-\mathbf{1 0 . 5 8} * * * \\
(3.613)\end{array}$ & $\begin{array}{c}-\mathbf{8 . 5 8 2} * * * \\
(2.151)\end{array}$ & $\begin{array}{c}\mathbf{0 . 3 9 7} * * \\
(0.152)\end{array}$ & $\begin{array}{c}\mathbf{0 . 1 4 7} * \\
(0.0881)\end{array}$ \\
\hline CAPINT & $\begin{array}{l}-1.625 \\
(1.619)\end{array}$ & $\begin{array}{l}-0.664 \\
(1.357)\end{array}$ & $\begin{array}{l}-0.241 \\
(0.355)\end{array}$ & $\begin{array}{l}-0.193 \\
(0.367)\end{array}$ & $\begin{array}{c}0.0181 \\
(0.0209)\end{array}$ & $\begin{array}{r}-0.0117 \\
(0.0293)\end{array}$ \\
\hline GROWTH & $\begin{array}{l}1.376 \\
(2.219)\end{array}$ & $\begin{array}{l}2.105 \\
(2.657)\end{array}$ & $\begin{array}{c}0.621 \\
(0.696)\end{array}$ & $\begin{array}{c}0.707 \\
(0.759)\end{array}$ & $\begin{array}{c}0.0122 \\
(0.0213)\end{array}$ & $\begin{array}{l}0.00303 \\
(0.0265)\end{array}$ \\
\hline RE.PENETRATION & $\begin{array}{l}\text { 1.612* } \\
(0.929)\end{array}$ & $\begin{array}{c}\mathbf{2 . 0 6 5} \text { ** } \\
(0.908)\end{array}$ & $\begin{array}{c}-0.00204 \\
(0.123)\end{array}$ & $\begin{array}{l}0.0507 \\
(0.120)\end{array}$ & $\begin{array}{c}-\mathbf{0 . 0 2 1 5} * * * * \\
(0.00790)\end{array}$ & $\begin{array}{c}-\mathbf{0 . 0 2 1 7} * * * * \\
(0.00792)\end{array}$ \\
\hline TIME & $\begin{array}{c}-\mathbf{0 . 9 2 2} * * * \\
(0.268)\end{array}$ & $\begin{array}{c}-\mathbf{0 . 9 9 8} * * * \\
(0.245)\end{array}$ & $\begin{array}{c}-\mathbf{0 . 2 6 8} * * * \\
(0.0552)\end{array}$ & $\begin{array}{c}-\mathbf{0 . 2 5 5} * * * \\
(0.0488)\end{array}$ & $\begin{array}{c}-\mathbf{0 . 0 1 6 1} * * * \\
(0.00288)\end{array}$ & $\begin{array}{c}-\mathbf{0 . 0 1 5 6} * * * * \\
(0.00289)\end{array}$ \\
\hline CONSTANT & $\begin{array}{c}\mathbf{1 , 8 8 6} * * * \\
(539.5)\end{array}$ & $\begin{array}{c}\mathbf{2 , 0 2 2} * * * \\
(493.3)\end{array}$ & $\begin{array}{c}\mathbf{5 4 9 . 5} * * * \\
(110.3)\end{array}$ & $\begin{array}{c}\mathbf{5 2 2 . 3} * * * \\
(98.14)\end{array}$ & $\begin{array}{c}\mathbf{3 2 . 6 5} * * * \\
(5.744)\end{array}$ & $\begin{array}{c}\mathbf{3 1 . 6 0} * * * \\
(5.801)\end{array}$ \\
\hline
\end{tabular}

\footnotetext{
${ }^{2}$ To save space these results are not reported here but are available from the authors.
} 


\begin{tabular}{lcccccc} 
Observations & 441 & 441 & 442 & 442 & 441 & 441 \\
Number of firms & 66 & 66 & 66 & 66 & 66 & 66 \\
& & & & & & \\
R-squared & & & & & & \\
within & 0.1548 & 0.1496 & 0.2851 & 0.2826 & 0.4638 & 0.4488 \\
between & 0.1521 & 0.1773 & 0.1250 & 0.1437 & 0.0459 & 0.2754 \\
overall & 0.1510 & 0.1672 & 0.1936 & 0.2072 & 0.1785 & 0.3062 \\
\hline
\end{tabular}

Robust standard errors in parentheses. ***, ** and * refer to $1 \%, 5 \%$ and $10 \%$ significance levels.

As the table shows, the results were rather similar under both the FE and RE models. RE.VOLUME was consistently negative for all the indicators, though the level of significance varied. The control variables SIZE, RISK, RE.PENETRATION and TIME were statistically significant in most of the models and their behavior was essentially in line with what we expected. SIZE had a positive coefficient, implying that larger companies also have higher ROE, ROA and Tobin's q. However, although the total debt to assets ratio (RISK) was negatively related to ROE and ROA, more debt to assets correlated positively with Tobin's q. This may indicate that risk-taking in the short term has negative repercussions on performance, but in the long run it may pay off. The renewable energy penetration variable had the highest variation between the models. For ROE it was positive and significant, for Tobin's q it was negative and significant, and for ROA it was not significant. What is notable is the negative and highly significant time trend, which shows that during the period 2005-2014 electric utilities experienced negative economic outcomes.

After we derived the basic regression analysis in Table 3, we ran the same models for developing and emerging markets separately (see Appendix C). We still saw that in developed economies the relationship between renewable energy production and the performance measure was negative and significant. The same also applies to the emerging markets, which suffered, however, from a limited number observations (only 86 firm-year observations).

The results illustrated in Table 3 show the concurrent effect of renewable energy production on performance. To add dynamism to our basic models, we introduced the first four lags (i.e., the observations from the previous four years) of RE.VOLUME to explain the performance measures. As Table 4 shows, although there is now more variation in the results, the negative relation between renewable energy and firm performance could still be noticed because all the significant RE.VOLUME variables with a lag of 2 or higher had a negative coefficient. For ROA 
the negative coefficients of lagged variables were clearly visible but there were fewer of them for ROE and Tobin's q.

By including the lagged values, some of the control variables lost their significance. RE.PENETRATION was significant in one model only and the time trend also lost its significance for all but Tobin's q models. CAPINT became significant for ROA and Tobin's q fixed effects and, for some reason, sales growth had a negative effect on Tobin's q. However, firm size and debt to assets ratio remained negative and significant for all of the models.

Table 4. Lagged renewable energy values and firm performance

\begin{tabular}{|c|c|c|c|c|c|c|}
\hline VARIABLES & $\begin{array}{l}\text { (FE) } \\
\text { ROE }\end{array}$ & $\begin{array}{l}\text { (RE) } \\
\text { ROE }\end{array}$ & $\begin{array}{l}(\mathrm{FE}) \\
\text { ROA }\end{array}$ & $\begin{array}{l}\text { (RE) } \\
\text { ROA } \\
\end{array}$ & $\begin{array}{l}(\mathrm{FE}) \\
\text { Tobin's q }\end{array}$ & $\begin{array}{l}(\mathrm{RE}) \\
\text { Tobin's q }\end{array}$ \\
\hline RE.VOLUME lag1 & $\begin{array}{l}-1.307 \\
(3.280)\end{array}$ & $\begin{array}{l}0.950 \\
(1.097)\end{array}$ & $\begin{array}{l}0.273 \\
(0.449)\end{array}$ & $\begin{array}{l}\text { 0.429* } \\
(0.232)\end{array}$ & $\begin{array}{l}0.00843 \\
(0.0143)\end{array}$ & $\begin{array}{l}0.0129 \\
(0.0218)\end{array}$ \\
\hline RE.VOLUME lag2 & $\begin{array}{l}-\mathbf{1 . 6 2 5} * \\
(0.934)\end{array}$ & $\begin{array}{l}-0.133 \\
(0.408)\end{array}$ & $\begin{array}{l}-\mathbf{0 . 3 7 4} * * * * \\
(0.131)\end{array}$ & $\begin{array}{l}-\mathbf{0 . 2 5 5} * * * * \\
(0.0672)\end{array}$ & $\begin{array}{l}-\mathbf{0 . 0 1 6 2} * \\
(0.00839)\end{array}$ & $\begin{array}{l}-0.0131 \\
(0.00908)\end{array}$ \\
\hline RE.VOLUME lag3 & $\begin{array}{l}-1.300 \\
(0.805)\end{array}$ & $\begin{array}{l}0.421 \\
(0.745)\end{array}$ & $\begin{array}{l}-\mathbf{0 . 3 3 8} * * \\
(0.149)\end{array}$ & $\begin{array}{l}-\mathbf{0 . 2 1 6} * * \\
(0.0910)\end{array}$ & $\begin{array}{l}-0.0121 \\
(0.00845)\end{array}$ & $\begin{array}{l}-0.00375 \\
(0.00835)\end{array}$ \\
\hline RE.VOLUME lag4 & $\begin{array}{l}-2.539 \\
(1.653)\end{array}$ & $\begin{array}{l}\mathbf{- 1 . 0 3 2} * \\
(0.543)\end{array}$ & $\begin{array}{l}-\mathbf{0 . 3 6 2} * * * \\
(0.128)\end{array}$ & $\begin{array}{l}-\mathbf{0 . 2 7 7} * * \\
(0.108)\end{array}$ & $\begin{array}{l}-\mathbf{0 . 0 0 9 2 6 *} \\
(0.00477)\end{array}$ & $\begin{array}{l}0.00842 \\
(0.00703)\end{array}$ \\
\hline SIZE & $\begin{array}{l}\text { 21.70* } \\
(12.35)\end{array}$ & $\begin{array}{l}\text { 19.83**** } \\
(5.411)\end{array}$ & $\begin{array}{l}\mathbf{2 . 4 1 6}^{*} \\
(1.310)\end{array}$ & $\begin{array}{l}\text { 3.368**** } \\
(1.017)\end{array}$ & $\begin{array}{l}\mathbf{0 . 4 4 4 * * *} \\
(0.0708)\end{array}$ & $\begin{array}{l}\mathbf{0 . 2 9 7} * * * \\
(0.0550)\end{array}$ \\
\hline RISK & $\begin{array}{l}-\mathbf{8 8 . 3 4} * * * * \\
(30.23)\end{array}$ & $\begin{array}{l}-\mathbf{3 7 . 5 3}^{\text {***** }} \\
(10.84)\end{array}$ & $\begin{array}{l}-12.45 * * \\
(5.585)\end{array}$ & $\begin{array}{l}-7.925 * * * * \\
(1.969)\end{array}$ & $\begin{array}{l}\text { 1.231**** } \\
(0.282)\end{array}$ & $\begin{array}{l}\text { 0.116* } \\
(0.0654)\end{array}$ \\
\hline CAPINT & $\begin{array}{l}-11.33 \\
(8.043)\end{array}$ & $\begin{array}{l}-0.194 \\
(2.513)\end{array}$ & $\begin{array}{l}-\mathbf{1 . 5 0 0 * *} \\
(0.653)\end{array}$ & $\begin{array}{l}-0.665 \\
(0.708)\end{array}$ & $\begin{array}{l}-\mathbf{0 . 1 0 1} * * * * \\
(0.0352)\end{array}$ & $\begin{array}{l}-0.00775 \\
(0.0139)\end{array}$ \\
\hline GROWTH & $\begin{array}{l}5.125 \\
(5.897)\end{array}$ & $\begin{array}{l}6.268 \\
(5.953)\end{array}$ & $\begin{array}{l}0.156 \\
(1.314)\end{array}$ & $\begin{array}{l}0.277 \\
(1.207)\end{array}$ & $\begin{array}{l}-\mathbf{0 . 0 8 3 5} * * * * \\
(0.0293)\end{array}$ & $\begin{array}{l}-\mathbf{0 . 0 9 1 5 * *} \\
(0.0402)\end{array}$ \\
\hline RE.PENETRATION & $\begin{array}{l}5.321 \\
(4.790)\end{array}$ & $\begin{array}{l}\mathbf{4 . 4 4 7 *} \\
(2.637)\end{array}$ & $\begin{array}{l}0.263 \\
(0.267)\end{array}$ & $\begin{array}{l}0.392 \\
(0.246)\end{array}$ & $\begin{array}{l}-0.000283 \\
(0.00758)\end{array}$ & $\begin{array}{l}-0.00854 \\
(0.0105)\end{array}$ \\
\hline TIME & $\begin{array}{l}-0.310 \\
(1.324)\end{array}$ & $\begin{array}{l}-0.745 \\
(0.539)\end{array}$ & $\begin{array}{l}-0.143 \\
(0.158)\end{array}$ & $\begin{array}{c}-0.0915 \\
(0.0998)\end{array}$ & $\begin{array}{l}-\mathbf{0 . 0 1 7 3} * * * \\
(0.00648)\end{array}$ & $\begin{array}{l}-\mathbf{0 . 0 1 9 5} * * * * \\
(0.00661)\end{array}$ \\
\hline CONSTANT & $\begin{array}{l}740.7 \\
(2,605)\end{array}$ & $\begin{array}{l}1,502 \\
(1,088)\end{array}$ & $\begin{array}{l}306.0 \\
(310.7)\end{array}$ & $\begin{array}{l}193.4 \\
(199.8)\end{array}$ & $\begin{array}{l}\mathbf{3 4 . 6 5}^{* * * *} \\
(12.86)\end{array}$ & $\begin{array}{l}\text { 39.17*** } \\
(13.29)\end{array}$ \\
\hline Observations & 197 & 197 & 197 & 197 & 197 & 197 \\
\hline Number of firms & 59 & 59 & 59 & 59 & 59 & 59 \\
\hline $\begin{array}{l}\text { R-squared } \\
\text { within } \\
\text { between } \\
\text { overall }\end{array}$ & $\begin{array}{l}0.1211 \\
0.1508 \\
0.0737\end{array}$ & $\begin{array}{l}0.0873 \\
0.2718 \\
0.1659\end{array}$ & $\begin{array}{l}0.1773 \\
0.1693 \\
0.1654\end{array}$ & $\begin{array}{l}0.1507 \\
0.2506 \\
0.2314\end{array}$ & $\begin{array}{l}0.6594 \\
0.0477 \\
0.0730\end{array}$ & $\begin{array}{l}0.5107 \\
0.2656 \\
0.3427\end{array}$ \\
\hline
\end{tabular}

Robust standard errors in parentheses. ${ }^{* * *},{ }^{* *}$ and $*$ refer to $1 \%, 5 \%$ and $10 \%$ significance levels. 
As for the possible moderation effect of carbon intensity, Table 5 reports the results when we introduced this variable and its interaction with RE.VOLUME. We present the results for ROA only because the interaction term was not significant for Tobin's q, and for ROE it was significant only under the FE model.

Table 5. Interaction between the volume of renewable energy and carbon intensity and effect on ROA

\begin{tabular}{|c|c|c|}
\hline VARIABLES & $\begin{array}{l}\text { (FE) } \\
\text { ROA } \\
\end{array}$ & $\begin{array}{l}\mathrm{RE}) \\
\mathrm{ROA}\end{array}$ \\
\hline RE.VOLUME & $\begin{array}{c}-\mathbf{0 . 3 6 2} * * \\
(0.158)\end{array}$ & $\begin{array}{c}-\mathbf{0 . 3 2 3} * * * * \\
(0.117)\end{array}$ \\
\hline SIZE & $\begin{array}{c}\mathbf{2 . 1 4 6} * * * \\
(0.582)\end{array}$ & $\begin{array}{c}\mathbf{2 . 4 6 9} * * * \\
(0.446)\end{array}$ \\
\hline RISK & $\begin{array}{c}-\mathbf{1 0 . 7 6} * * * * \\
(3.706)\end{array}$ & $\begin{array}{c}\mathbf{- 9 . 5 2 3} * * * * \\
(2.318)\end{array}$ \\
\hline CAPINT & $\begin{array}{l}-0.222 \\
(0.350)\end{array}$ & $\begin{array}{r}-0.219 \\
(0.340)\end{array}$ \\
\hline GROWTH & $\begin{array}{c}0.758 \\
(0.788)\end{array}$ & $\begin{array}{c}0.872 \\
(0.883)\end{array}$ \\
\hline RE.PENETRATION & $\begin{array}{l}0.0233 \\
(0.137)\end{array}$ & $\begin{array}{l}0.0929 \\
(0.130)\end{array}$ \\
\hline CARBINT & $\begin{array}{c}\mathbf{- 2 . 4 0 6 *} \\
(1.428)\end{array}$ & $\begin{array}{c}-\mathbf{2 . 2 1 6} * * \\
(0.985)\end{array}$ \\
\hline RE.VOLUME x CARBINT & $\begin{array}{c}\mathbf{0 . 1 6 8}^{*} \\
(0.0959)\end{array}$ & $\begin{array}{l}\mathbf{0 . 1 5 7} * * \\
(0.0669)\end{array}$ \\
\hline TIME & $\begin{array}{c}-\mathbf{0 . 2 5 6} * * * * \\
(0.0631)\end{array}$ & $\begin{array}{c}-\mathbf{0 . 2 4 2} * * * \\
(0.0505)\end{array}$ \\
\hline CONSTANT & $\begin{array}{c}\mathbf{5 2 8 . 7} * * * * \\
(126.2)\end{array}$ & $\begin{array}{c}\text { 498.5*** } \\
(101.7)\end{array}$ \\
\hline $\begin{array}{l}\text { Observations } \\
\text { Number of firms } \\
\text { R-squared } \\
\text { within } \\
\text { between } \\
\text { overall }\end{array}$ & $\begin{array}{l}0.2811 \\
0.1546 \\
0.2192 \\
\end{array}$ & $\begin{array}{c}412 \\
64 \\
0.2792 \\
0.1756 \\
0.2307 \\
\end{array}$ \\
\hline
\end{tabular}

As Table 5 shows, RE.VOLUME and most of the control variables still behaved similarly to the previous models. CARBINT was negative and statistically significant whereas its interaction with RE.VOLUME was statistically significant but positive. In order to understand the moderation effect of CARBINT, we calculated the slope of our dependent variable on the 
independent variable when the moderator assumes a high value (high carbon intensity) and when it assumes a low value (low carbon intensity). We did this by centering CARBINT one standard deviation above and one standard deviation below the mean. Figure 2 shows the regression lines when holding the moderator variable constant at its high and low values. We can see that when firms have high carbon intensity (i.e., the moderator is kept at its highest value), the correlation between ROA and RE.VOLUME becomes positive whereas in the opposite case it is negative.

Figure 2. Moderating effect of carbon intensity

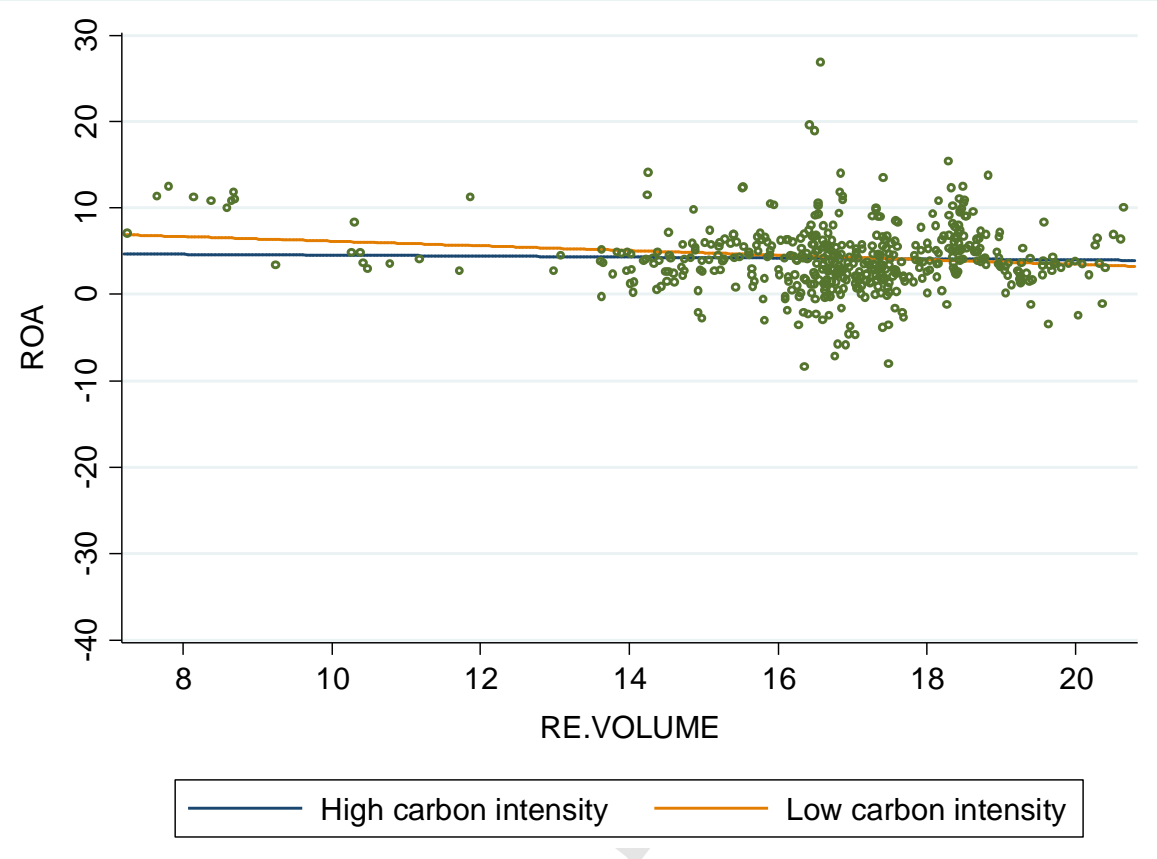

To complete the analysis of the correlations, we examined the economic significance of our variables. Because the variables have not been standardized to any specific interval, comparing their coefficients does not provide any indication of which ones are the most important for firm performance. In Table 6 we provide measures for the economic significance of our results. 
Table 6. Economic significance

\begin{tabular}{lcccccc}
\hline VARIABLES & $\begin{array}{c}\text { ROE } \\
(\mathrm{FE})\end{array}$ & $\begin{array}{c}\text { ROE } \\
(\mathrm{RE})\end{array}$ & $\begin{array}{c}\text { ROA } \\
(\mathrm{FE})\end{array}$ & $\begin{array}{c}\text { ROA } \\
(\mathrm{RE})\end{array}$ & $\begin{array}{c}\text { Tobin's q } \\
(\mathrm{FE})\end{array}$ & $\begin{array}{c}\text { Tobin's q } \\
(\mathrm{RE})\end{array}$ \\
\hline RE.VOLUME & -0.090 & -0.018 & -0.019 & -0.032 & -0.002 & -0.001 \\
SIZE & 0.603 & 0.685 & 0.100 & 3.478 & 0.012 & 0.072 \\
RISK & -0.303 & -0.057 & -0.070 & -0.177 & 0.003 & 0.001 \\
CAPINT & -0.055 & -0.007 & -0.008 & -0.022 & 0.001 & 0.000 \\
GROWTH & 0.018 & 0.009 & 0.008 & 0.028 & 0.000 & 0.000 \\
RE.PENETRATION & 0.058 & 0.002 & 0.000 & 0.074 & -0.001 & -0.001 \\
\hline
\end{tabular}

Economic significance was calculated as the product of estimated coefficient (from Table 3) and one standard deviation of each variable (from Table 2, except for SIZE where the economic significance was calculated using standard deviation of the de-trended logarithm of total asset value, 0.274). As can be seen, SIZE had by far the largest effect on the performance measures and RISK the second highest. The volume of renewable energy was the third largest (in absolute terms) and all the rest of the variables were smaller than in most estimations. The three most economically significant variables were also those that were consistently statistically significant in almost all the models of Table 3.

All in all, although the significances between our estimations vary, all of our models found a negative correlation between the amount of renewable energy produced and firm performance measures. Firm size was clearly the most important determinant of firm performance, but the renewable energy volume had a notable effect on it as well.

\subsection{Robustness check}

Although in our basic model we have already partially controlled for countries support to renewable energy with RE.PENETRATION variable, we wanted to verify the robustness of our results by including a dummy variable for each country-year where a country has used subsidies or regulations to boost its renewable energy capacity. For this, we created three dummy variables: FIT_IEA, FIT_REN21, QUOTA/RPS_REN21. The first two dummies assume a value of 1 for the years when there was a feed-in tariff scheme in a firm's home country and 0 if there was not. The only difference between the two is the origin of the data. In the first case, data were from the Global Renewable Energy Policies and Measures Database (IEA/IRENA, 2016) and in 
the second from the annual reports on the renewable energy market, industry and policy trends published by REN21 (REN21, 2016). The third dummy, in contrast, assumes a value of 1 for the years when there was a quota obligation or renewable portfolio standards (RPS) in the home market of the electric utility and 0 if there was not. For the last dummy we have data only from REN21 reports. When a policy mechanism was not available at the national level, like in the case of feed-in tariff in the US and Canada, we formed the variables at the regional level, checking if the company's headquarters were located in the region/state in question.

Subsequently, we estimated the same models as in Table 3 but, for reasons of space, only the result for the variables of interests (i.e., RE.VOLUME and the dummy variables) is included in Table $7^{3}$. As can be seen, the results for RE.VOLUME remained consistent. Thus, the presence of a feed-in tariff scheme or a quota obligation / RPS did not have an effect on our original estimations, because the relationship between the amount of renewable energy and the performance measures remains negative.

One surprising finding was the fact that almost all the coefficients of the dummies were negative. However, in the case of quota obligation / RPS under the FE model, for ROE and ROA they were positive and significant, but for Tobin's q they were, again, negative. When interpreting the coefficients of the dummies, we need to be careful because, even though they are mainly negative, several are not significant. All in all, the main finding from the robustness check was that our original results did not change when we explicitly controlled for the role of feed-in tariff and quota obligation / $\operatorname{RPS}^{4}$ schemes.

Table 7. Renewable energy, feed-in tariff, quota obligation / RPS and firm performance

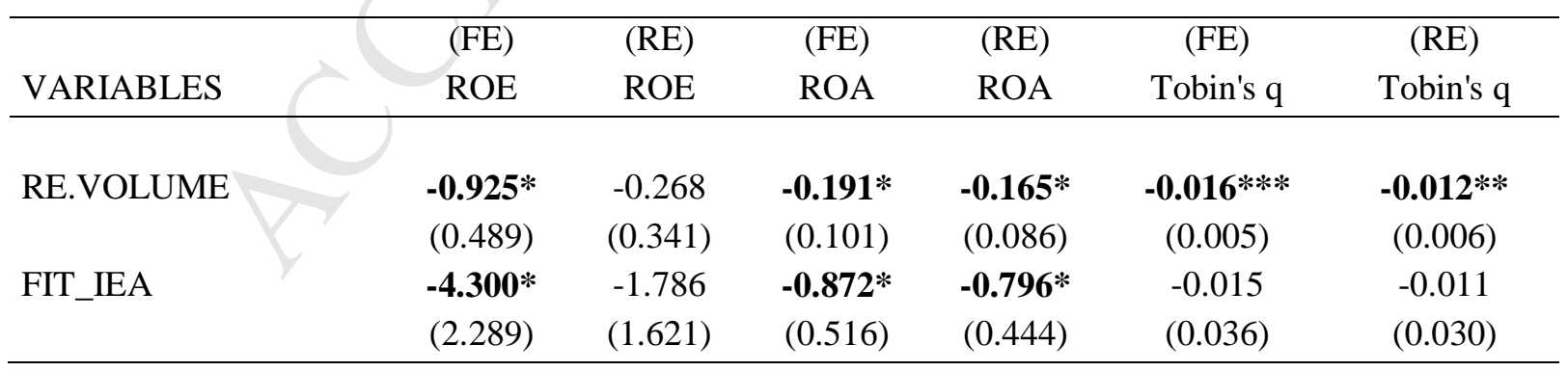

\footnotetext{
${ }^{3}$ Coefficients for the rest of the control variables remain rather similar between each estimated model and are available from the authors.

${ }^{4}$ To further study the regional and country related differences, we also estimated the random effects models by including regional and country dummies. The results, which are available from the authors, remained the same.
} 


\begin{tabular}{lcccccc}
\hline RE.VOLUME & $\mathbf{- 0 . 9 1 1 *}$ & -0.263 & $\mathbf{- 0 . 1 8 5} *$ & $\mathbf{- 0 . 1 6 2} *$ & $\mathbf{- 0 . 0 1 7 * * *}$ & $\mathbf{- 0 . 0 1 2 * *}$ \\
& $(0.484)$ & $(0.348)$ & $(0.098)$ & $(0.086)$ & $(0.005)$ & $(0.006)$ \\
FIT_REN21 & -2.117 & -0.807 & -0.351 & -0.338 & -0.038 & -0.023 \\
& $(1.634)$ & $(1.675)$ & $(0.431)$ & $(0.399)$ & $(0.031)$ & $(0.024)$ \\
\hline RE.VOLUME & $\mathbf{- 0 . 8 6 1 *}$ & -0.297 & $\mathbf{- 0 . 1 7 9 *}$ & $\mathbf{- 0 . 1 7 1 * *}$ & $\mathbf{- 0 . 0 1 6 * * *}$ & $\mathbf{- 0 . 0 1 2 * *}$ \\
& $(0.495)$ & $(0.334)$ & $(0.101)$ & $(0.086)$ & $(0.005)$ & $(0.006)$ \\
QUOTA/RPS_REN21 & $\mathbf{2 . 0 6 2 *}$ & -0.322 & $\mathbf{0 . 5 8 7} * *$ & 0.399 & $\mathbf{- 0 . 0 2 8} * *$ & $\mathbf{- 0 . 0 4 4 * *}$ \\
& $(1.177)$ & $(1.786)$ & $(0.282)$ & $(0.352)$ & $(0.012)$ & $(0.020)$ \\
\hline
\end{tabular}

Robust standard errors in parentheses. ${ }^{* * *}, * *$ and $*$ refer to $1 \%, 5 \%$ and $10 \%$ significance levels.

\subsection{Granger causality test}

Even though Table 3 already provided evidence that higher amounts of renewable energy production may lead to negative firm performance, we tested the causation more formally and also in both directions. Due to data limitations, however, we only tested for lengths of 2, 3, 4 and 5. The results (the F-test statistics of a joint null hypothesis that all coefficients of $\mathrm{X}$ are zero as well as the corresponding $\mathrm{p}$ values) can be found in Table 8.

Table 8. Granger causality test between renewable energy production and performance measures

\begin{tabular}{lllll}
\hline & Lag 2 & Lag 3 & Lag 4 & Lag 5 \\
RE.VOLUME $\nRightarrow$ ROA & 1.943 & 1.222 & 0.924 & 0.652 \\
RE.VOLUME $\nRightarrow$ ROE & 0.145 & 0.302 & 0.451 & 0.660 \\
& 0.406 & 0.206 & 0.266 & 0.317 \\
RE.VOLUME $\Rightarrow$ Tobin's q & 0.666 & 0.892 & 0.900 & 0.902 \\
ROA $\nRightarrow$ RE.VOLUME & $\mathbf{2 . 8 6 1 *}$ & $\mathbf{2 . 6 9 3 * *}$ & 0.143 & 1.160 \\
ROE $\nRightarrow$ RE.VOLUME & 0.059 & 0.047 & 0.966 & 0.332 \\
Tobin's q $\Rightarrow$ RE.VOLUME & 0.571 & 1.214 & 0.480 & 0.615 \\
& 0.565 & 0.305 & 0.751 & 0.688 \\
Observations & 1.255 & 1.592 & 0.574 & 0.390 \\
\hline
\end{tabular}

Note: Table 8 shows the results of the Granger causality test for different lag lengths. The null hypothesis is that the variable on the left does not Granger-cause the variable on the right. The table shows $\mathrm{F}$ statistics and its corresponding p value below. $* *$ and * refer to statistically significant results at the 5\% and $10 \%$ levels.

For ROA and ROE the null hypothesis was not rejected for any of the cases, meaning that there was no Granger causality with the renewable energy production in either direction. However, we found that for lags of 2 and 3 there was a statistically significant relationship from renewable 
energy to Tobin's q and for a lag length of 3, the direction also goes the other way. When the regressions were carried out using equations (2) and (3), we found that all the lagged coefficients of RE.VOLUME were negative, thus providing even more evidence for the negative relationship between Tobin's q and renewable energy production.

\section{Discussion and Conclusions}

The aim of this study was to verify if the NRBV of a firm can also be applied in the case of clean technology. To find some empirical evidence we used the example of electric utilities switching to renewable power production. In general, our results support a negative relationship between an increase in renewable energy production and both short-term and long-term FP. This is partially congruent with Sueyoshi and Goto (2009), who pointed out that the higher capital costs of renewable energy affect the FP of electric utilities in the short term. In contrast to Sueyoshi and Goto (2009), however, we also found that an increase in renewable energy production Granger-causes a reduction of firms' long-term FP. In addition, our findings indicate that the relationship between an increase in renewable power production and profitability is contingent on the level of carbon intensity of the firm. Therefore, firms that have a high level of CO2 emissions may benefit more from the deployment of renewable electricity than firms with low $\mathrm{CO} 2$ emissions. Based on these results, we are inclined to think that the NRBV may not apply to the case of utilities increasing renewable energy production.

The presence of the moderating effect of carbon intensity answers our second research question positively and is in line with previous research (Hart and Ahuja, 1996). Moreover, it echoes Aragón-Correa and Sharma (2003), who proposed a contingent-resource-based view of proactive corporate environmental strategy. Because carbon intensity plays a role in moderating the relationship between the increase of renewable energy and a firm's performance, there may be, for firms that have already deployed renewable energy to some extent, an equilibrium point beyond which any increase in its capacity may be economically detrimental. After all, if the deployment of renewable energy always boosted a firm's FP, why is it that of the top 100 greenest utilities in the world, only five had a share of renewable energy higher than $20 \%$ at the end of the period under examination (Energy Intelligence, 2014; note that the figures do not include hydropower)? 
The idea that electric utilities may need to balance profits from conventional assets with investment in renewables can be easily understood in light of the organizational ambidexterity perspective (March, 1991). According to this view, firms need to ensure that they have an optimal mix of exploration and exploitation activities to ensure success in the short and long term. In our case, exploitation activities are utilities' existing fossil fuel investments, and exploration activities are the deployment of renewable energy. We propose that the concept of ambidexterity (Gupta et al., 2013; Raisch et al., 2009) may be used to refine the NRBV understanding of the link between the processes of environmental change for sustainability within the firm and its performance.

When this concept is applied here, we arrive at one broad implication of our findings: due to the need of incumbent firms to balance their exploitative and explorative activities, they may promote only a gradual development of renewable energy. Thus, in general terms, to accelerate the shift to clean energy production the participation of new actors needs to be promoted (see also Ruggiero et al., 2015).

A further interesting finding of our study is the fact that also the correlation between the share of renewable power of a firm's home country and firm's long-term performance was negative. This result could be explained by the fact that the expansion of renewable energy contributes to the devaluation of firms' fossil fuel assets. When renewable capacity increases, the overall quantity of electricity available on the market increases. A higher availability of electricity leads to lower wholesale prices and, consequently, lower margins for conventional power plants (The Economist, 2013). The concern in the investor community regarding the impact of renewable energy expansion on electricity prices is well illustrated in the following quote from a report by Moody's (2012):

Large increases in renewables have had a profound negative impact on power prices and the competitiveness of thermal generation companies in Europe. What were once considered stable companies have seen their business models severely disrupted, and we expect steadily rising levels of renewable energy output to further affect European utilities' creditworthiness. 
Evidence of a reduction in the value of electric utilities' assets, which in accounting is called impairment (Accounting Dictionary, 2016), can be found also in a recent report by Ernst \& Young (2013). The report showed that between 2010 and 2013 large utilities wrote a total of $€ 62.7$ billion in impairments off their balance sheets.

With regard to the role of subsidies and regulation, the results of the robustness check showed that the sign of the correlation between renewable energy increase and profitability does not change when controlling for the presence of a feed-in tariff or a quota obligation scheme. However, companies operating in countries with a non-feed-in tariff regime as well as companies operating in countries with a quota obligation / RPS system have higher short-term performance compared to the rest. Although this result requires further validation because it was found only under a FE estimation model, it can be explained by the different nature of the two policy mechanisms. The feed-in tariff system supports new and small-scale producers, leaving the burden of integrating renewable energy to incumbent power companies (Verbruggen and Lauber, 2012). Obligation quota / RPS schemes, instead, boost incumbent power companies' profits, leaving only a minor part of the economic benefits of renewable energy to new producers (Bergek and Jacobsson, 2010; Stenzel and Frenzel, 2008, Verbruggen and Lauber, 2012).

An important remark needs to be made here about the negative time trend variable we found. It suggests that the growth of renewable energy capacity driven by falling technology costs and subsidies is not the only factor that has contributed to the reduction of firms' profitability. Other important factors may also include, for example, cheap natural gas, a stagnant demand for electricity, overcapacity, nuclear phase-outs in some countries and the financial crisis. At play, therefore, are unfavorable market conditions in combination with the growth of renewable energy.

Before concluding, we feel it is important to highlight some of the limitations of this study. First, because we used unbalanced data, some companies might have had a larger effect on the results than others. This became clear when we compared developed and emerging countries, where the former had about four times more observations. Thus, our sample set was heavily tilted towards developed countries and their more mature electricity markets. Second, we were able to 
introduce only four lagged values of our key explanatory variable, but investments in the energy sector may take a long time to pay themselves back. Last, we measured firm performance only in terms of short- and long-term FP. Future research may instead apply other parameters to measure performance, such as avoided negative externalities.

We conclude this article with two final thoughts. Although our study showed that the deployment of renewable energy may not necessarily have positive economic implications (at the least) for electric utilities operating in mature markets (i.e., those markets affected by overcapacity, declining demand and so on), this should not restrain them from seriously answering the global call for increasing the share of renewable energy. The problem, in fact, may not be the adoption of more renewable energy per se but the challenging task of balancing it with conventional generation while gradually phasing out fossil fuels. Second, our findings are bound to the assumption that utilities will continue deploying renewable energy with a traditional centralized model. However, in the near future customer-side models (Richter, 2012) will play a central role. We believe much of the future of the industry depends on its ability to rethink its business model and develop new core competences that leverage the versatility of renewable energy technology.

\section{Acknowledgements}

This study was carried out with funding from the University of Jyväskylä. The main author wishes to thank Professor Maurizio Zollo from the University Bocconi of Milano for the interesting discussions that stimulated part of this research. 


\section{Appendix A}

Number of firms per world regions/countries

EU

Austria

Czech Republic

Finland

France

Germany

Greece

Italy

Poland

Portugal

Russia

Spain

Switzerland

UK

NA

Canada

US
19 EA

1 China

1 India

1 Japan

2 Malaysia

2 New Zealand

1 Philippines

3 South Korea

1

1 SA

1 Bolivia

2 Brazil

1 Chile

2 Colombia

20

3

17

Total
20

3

2

11

1

1

1

1

\section{7}

1

4

1

1

66 


\section{Appendix B}

Scatter plots with a fitted line for ROE, ROA and Tobin's q with respect to RE.VOLUME
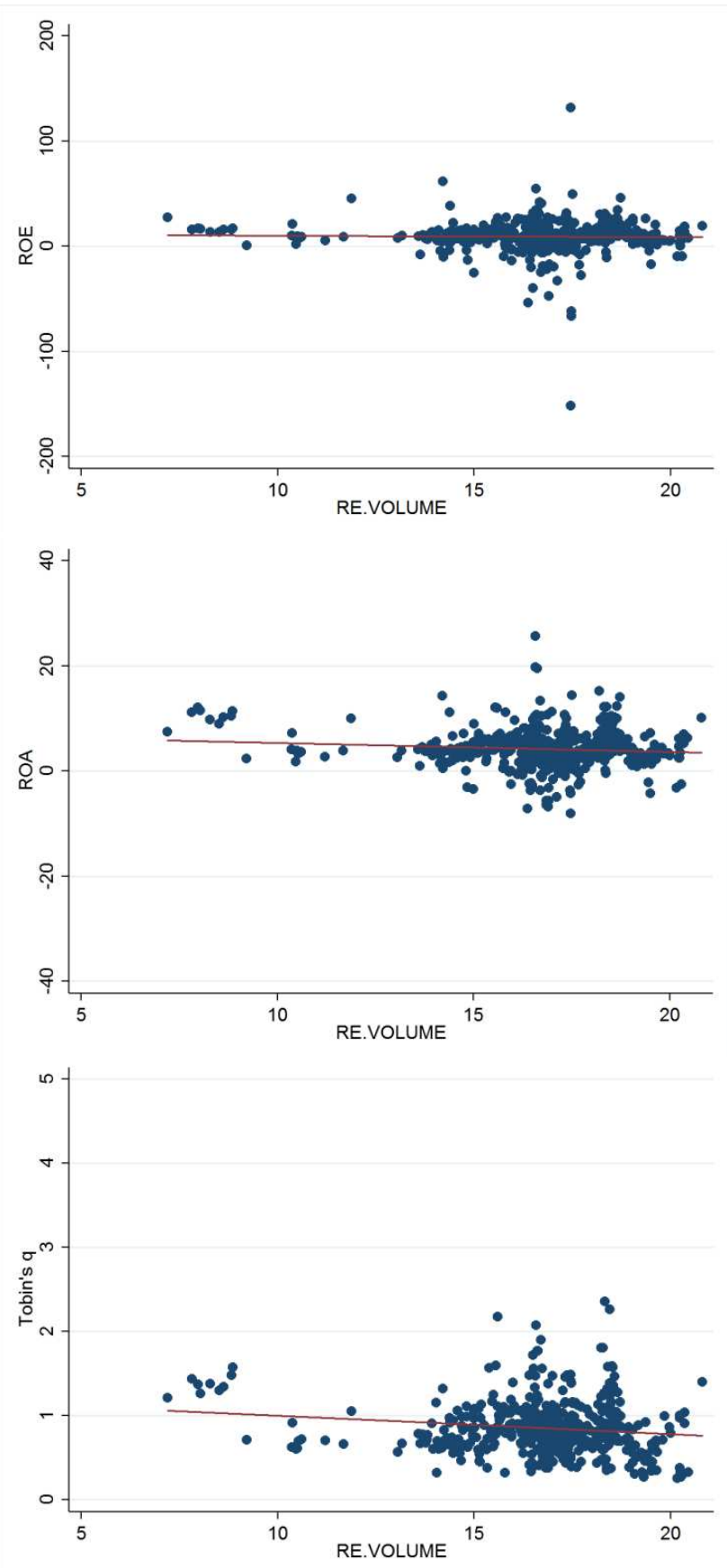
Appendix C

Panel 1. Random effects model for firms from developed and emerging markets.

\begin{tabular}{|c|c|c|c|c|c|c|}
\hline VARIABLES & $\begin{array}{l}\text { (DE) } \\
\text { ROE } \\
\end{array}$ & $\begin{array}{l}(\mathrm{EM}) \\
\mathrm{ROE} \\
\end{array}$ & $\begin{array}{l}(\mathrm{DE}) \\
\mathrm{ROA} \\
\end{array}$ & $\begin{array}{l}\text { (EM) } \\
\text { ROA } \\
\end{array}$ & $\begin{array}{l}(\mathrm{DE}) \\
\text { Tobin's q }\end{array}$ & $\begin{array}{l}(\mathrm{EM}) \\
\text { Tobin's q }\end{array}$ \\
\hline RE.VOLUME & $\begin{array}{l}-0.283 \\
(0.328)\end{array}$ & $\begin{array}{l}-1.505 \\
(1.219)\end{array}$ & $\begin{array}{l}-\mathbf{0 . 2 1 1} * * \\
(0.103)\end{array}$ & $\begin{array}{l}-\mathbf{- 0 . 7 6 6 *} \\
(0.458)\end{array}$ & $\begin{array}{l}0.00515 \\
(0.00333)\end{array}$ & $\begin{array}{l}-\mathbf{0 . 0 5 3 5 *} \\
(0.0279)\end{array}$ \\
\hline SIZE & $\begin{array}{l}\text { 12.69**** } \\
(3.403)\end{array}$ & $\begin{array}{l}\text { 8.867*** } \\
(4.346)\end{array}$ & $\begin{array}{l}\mathbf{2 . 1 6 6 * * * *} \\
(0.402)\end{array}$ & $\begin{array}{l}\mathbf{3 . 3 4 5}^{* * *} \\
(1.595)\end{array}$ & $\begin{array}{l}\mathbf{0 . 2 1 3} * * * \\
(0.0413)\end{array}$ & $\begin{array}{l}\mathbf{0 . 2 9 7} * * * \\
(0.113)\end{array}$ \\
\hline RISK & $\begin{array}{l}\mathbf{- 3 7 . 7 9} * * * \\
(8.604)\end{array}$ & $\begin{array}{l}\mathbf{2 2 . 1 4} \\
(14.97)\end{array}$ & $\begin{array}{l}\mathbf{- 1 0 . 6 7 * * * *} \\
(1.844)\end{array}$ & $\begin{array}{l}4.615 \\
(5.783)\end{array}$ & $\begin{array}{l}-0.0241 \\
(0.0311)\end{array}$ & $\begin{array}{l}-0.0440 \\
(0.173)\end{array}$ \\
\hline CAPINT & $\begin{array}{l}1.405 \\
(1.327)\end{array}$ & $\begin{array}{l}\mathbf{- 2 . 4 3 9 *} \\
(1.451)\end{array}$ & $\begin{array}{l}0.485 \\
(0.309)\end{array}$ & $\begin{array}{l}\mathbf{- 1 . 0 9 6 * *} \\
(0.490)\end{array}$ & $\begin{array}{l}\mathbf{0 . 0 2 2 7 *} \\
(0.0120)\end{array}$ & $\begin{array}{l}-0.0182 \\
(0.0380)\end{array}$ \\
\hline GROWTH & $\begin{array}{l}3.791 \\
(3.081)\end{array}$ & $\begin{array}{l}0.709 \\
(2.435)\end{array}$ & $\begin{array}{l}0.919 \\
(0.583)\end{array}$ & $\begin{array}{l}0.323 \\
(1.029)\end{array}$ & $\begin{array}{l}\mathbf{0 . 0 8 4 1} * * * \\
(0.0299)\end{array}$ & $\begin{array}{l}-0.0435 \\
(0.0311)\end{array}$ \\
\hline RE.PENETRATION & $\begin{array}{l}\text { 2.921**** } \\
(1.130)\end{array}$ & $\begin{array}{l}0.347 \\
(1.029)\end{array}$ & $\begin{array}{l}0.0907 \\
(0.138)\end{array}$ & $\begin{array}{l}-0.0463 \\
(0.279)\end{array}$ & $\begin{array}{l}-\mathbf{0 . 0 1 4 7 *} * \\
(0.00845)\end{array}$ & $\begin{array}{l}-\mathbf{0 . 0 3 8 9} * * * \\
(0.0113)\end{array}$ \\
\hline TIME & $\begin{array}{l}-\mathbf{1 . 0 6 0} * * * \\
(0.274)\end{array}$ & $\begin{array}{l}-\mathbf{1 . 1 8 7} * * \\
(0.534)\end{array}$ & $\begin{array}{l}-\mathbf{0 . 2 7 3} * * * * \\
(0.0485)\end{array}$ & $\begin{array}{l}-\mathbf{0 . 4 0 3 *} \\
(0.229)\end{array}$ & $\begin{array}{l}-\mathbf{0 . 0 1 8 9} * * * \\
(0.00307)\end{array}$ & $\begin{array}{l}-0.00868 \\
(0.00877)\end{array}$ \\
\hline CONSTANT & $\begin{array}{l}\mathbf{2 , 1 5 3} * * * * \\
(550.2)\end{array}$ & $\begin{array}{l}\mathbf{2 , 4 1 3} * * \\
(1,073)\end{array}$ & $\begin{array}{l}\mathbf{5 5 9 . 8}^{* * * *} \\
(97.49)\end{array}$ & $\begin{array}{l}\text { 827.1* } \\
(462.1)\end{array}$ & $\begin{array}{l}37.92 * * * \\
(6.167)\end{array}$ & $\begin{array}{l}18.43 \\
(17.50)\end{array}$ \\
\hline Observations & 355 & 86 & 356 & 86 & 356 & 85 \\
\hline $\begin{array}{l}\text { Number of firms } \\
\text { R-squared }\end{array}$ & 50 & 16 & 50 & 16 & 50 & 16 \\
\hline $\begin{array}{l}\text { within } \\
\text { between } \\
\text { overall }\end{array}$ & $\begin{array}{l}0.1562 \\
0.3656 \\
0.2133 \\
\end{array}$ & $\begin{array}{l}0.2308 \\
0.4052 \\
0.3324 \\
\end{array}$ & $\begin{array}{l}0.3161 \\
0.3408 \\
0.3347 \\
\end{array}$ & $\begin{array}{l}0.2457 \\
0.3513 \\
0.3143 \\
\end{array}$ & $\begin{array}{l}0.4482 \\
0.3669 \\
0.4322 \\
\end{array}$ & $\begin{array}{l}0.5051 \\
0.6545 \\
0.4984 \\
\end{array}$ \\
\hline
\end{tabular}

Panel 2. Fixed effects model for firms from developed and emerging markets.

\begin{tabular}{|c|c|c|c|c|c|c|}
\hline VARIABLES & $\begin{array}{l}\text { (DE) } \\
\text { ROE }\end{array}$ & $\begin{array}{l}\text { (EM) } \\
\text { ROE }\end{array}$ & $\begin{array}{l}\text { (DE) } \\
\text { ROA }\end{array}$ & $\begin{array}{l}\text { (EM) } \\
\text { ROA }\end{array}$ & $\begin{array}{l}(\mathrm{DE}) \\
\text { Tobin's q }\end{array}$ & $\begin{array}{l}(\mathrm{EM}) \\
\text { Tobin's q }\end{array}$ \\
\hline RE.VOLUME & $\begin{array}{l}-\mathbf{0 . 9 2 8} * \\
(0.515)\end{array}$ & $\begin{array}{l}-\mathbf{3 . 7 2 0} * \\
(2.048)\end{array}$ & $\begin{array}{l}-\mathbf{0 . 1 9 5} * \\
(0.104)\end{array}$ & $\begin{array}{l}-0.651 \\
(0.902)\end{array}$ & $\begin{array}{l}-\mathbf{0 . 0 1 5 0} * * * * \\
(0.00557)\end{array}$ & $\begin{array}{l}-0.0454 \\
(0.0335)\end{array}$ \\
\hline SIZE & $\begin{array}{l}\text { 13.76**** } \\
(4.367)\end{array}$ & $\begin{array}{l}8.819 \\
(5.584)\end{array}$ & $\begin{array}{l}\text { 1.994**** } \\
(0.526)\end{array}$ & $\begin{array}{l}2.880 \\
(2.142)\end{array}$ & $\begin{array}{l}\mathbf{0 . 2 4 0} * * * \\
(0.0498)\end{array}$ & $\begin{array}{l}\mathbf{0 . 2 5 9} * * \\
(0.0957)\end{array}$ \\
\hline RISK & $\begin{array}{l}-61.15 * * * \\
(21.45)\end{array}$ & $\begin{array}{l}16.52 \\
(16.37)\end{array}$ & $\begin{array}{l}-\mathbf{1 3 . 7 5} * * * * \\
(3.966)\end{array}$ & $\begin{array}{l}-0.0174 \\
(5.669)\end{array}$ & $\begin{array}{l}\mathbf{0 . 4 3 2} * * \\
(0.173)\end{array}$ & $\begin{array}{l}0.106 \\
(0.221)\end{array}$ \\
\hline CAPINT & $\begin{array}{l}0.204 \\
(2.334)\end{array}$ & $\begin{array}{l}-1.909 \\
(1.485)\end{array}$ & $\begin{array}{l}0.425 \\
(0.349)\end{array}$ & $\begin{array}{l}-\mathbf{1 . 1 8 7} * * \\
(0.538)\end{array}$ & $\begin{array}{l}0.0254 \\
(0.0315)\end{array}$ & $\begin{array}{l}0.0167 \\
(0.0170)\end{array}$ \\
\hline GROWTH & $\begin{array}{l}3.239 \\
(2.630)\end{array}$ & $\begin{array}{l}0.723 \\
(2.356)\end{array}$ & $\begin{array}{l}\text { 0.959* } \\
(0.571)\end{array}$ & $\begin{array}{l}0.230 \\
(0.968)\end{array}$ & $\begin{array}{l}\mathbf{0 . 0 8 8 5} \text { **** } \\
(0.0300)\end{array}$ & $\begin{array}{l}-0.0318 \\
(0.0269)\end{array}$ \\
\hline RE.PENETRATION & $\begin{array}{l}1.976 \\
(1.185)\end{array}$ & $\begin{array}{l}0.373 \\
(0.979)\end{array}$ & $\begin{array}{l}0.0111 \\
(0.138)\end{array}$ & $\begin{array}{l}-0.0298 \\
(0.302)\end{array}$ & $\begin{array}{l}-0.0133 \\
(0.00898)\end{array}$ & $\begin{array}{l}-\mathbf{0 . 0 4 1 9} * * * * \\
(0.0105)\end{array}$ \\
\hline TIME & $-0.896 * * *$ & -0.989 & $-0.267 * * *$ & -0.427 & $-0.0174 * * *$ & -0.00586 \\
\hline
\end{tabular}




\begin{tabular}{|c|c|c|c|c|c|c|}
\hline & $(0.322)$ & $(0.666)$ & $(0.0521)$ & $(0.280)$ & $(0.00298)$ & $(0.00822)$ \\
\hline CONSTANT & $\begin{array}{l}\mathbf{1 , 8 4 2 * * *} \\
(650.4)\end{array}$ & $\begin{array}{l}2,058 \\
(1,326)\end{array}$ & $\begin{array}{l}\mathbf{5 4 8 . 6}^{* * * *} \\
(104.5)\end{array}$ & $\begin{array}{l}875.2 \\
(556.2)\end{array}$ & $\begin{array}{l}\text { 35.08*** } \\
(5.970)\end{array}$ & $\begin{array}{l}12.66 \\
(16.23)\end{array}$ \\
\hline Observations & 355 & 86 & 356 & 86 & 356 & 85 \\
\hline Number of firms & 50 & 16 & 50 & 16 & 50 & 16 \\
\hline $\begin{array}{l}\text { R-squared } \\
\text { within }\end{array}$ & 0.1395 & 0.2500 & 0.2938 & 0.2662 & 0.4381 & 0.3907 \\
\hline between & 0.3967 & 0.3670 & 0.3809 & 0.3276 & 0.3308 & 0.7105 \\
\hline overall & 0.2187 & 0.3136 & 0.3460 & 0.3111 & 0.4193 & 0.5634 \\
\hline
\end{tabular}

Robust standard errors in parentheses. ${ }^{* * *},{ }^{* *}$ and $*$ refer to $1 \%, 5 \%$ and $10 \%$ significance levels. 


\section{List of References}

Accounting Dictionary, 2016. Impairment. Available at:

http://www.accountingtools.com/definition-impairment (Accessed 10 June 2016).

Albertini, E., 2013. Does Environmental Management Improve Financial Performance? A MetaAnalytical Review. Organization \& Environment, 26, 431-457.

Allison, P., 2009. Fixed Effects Regression Models. In Quantitative Applications in the Social Sciences, SAGE Publications Inc., Thousand Oaks, California.

Ambec, S., Lanoie, P., 2008. Does It Pay to Be Green? A Systematic Overview. Academy of Management Perspectives, 22, 45-62.

Anuta, O.H., Taylor, P., Jones, D., McEntee, T., Wade, N., 2014. An international review of the implications of regulatory and electricity market structures on the emergence of grid scale electricity storage. Renewable and Sustainable Energy Reviews, 38, 489-508.

Aragon-Correa, J.A., 1998. Strategic proactivity and firm approach to the natural environment. Academy of Management Journal, 41, 556-567.

Aragón-Correa, J.A., Hurtado-Torres, N., Sharma, S., García-Morales, V.J., 2008. Environmental strategy and performance in small firms: A resource-based perspective. Journal of environmental management, 86, 88-103.

Aragón-Correa, J.A., Sharma, S., 2003. A Contingent Resource-Based View of Proactive Corporate Environmental Strategy. The Academy of Management Review, 28(1), 71-88.

Bacon, R.W., Besant-Jones, J., 2001. Global electric power reform, privatization, and liberalization of the electric power industry in developing countries. Annual Review of Energy and the Environment, 26, 331-359. 
Baltagi, B., 2008. Econometric Analysis of Panel Data, 4th ed. John Wiley \& Sons.

Bergek, A., Jacobsson, S., 2010. Are tradable green certificates a cost-efficient policy driving technical change or a rent-generating machine? Lessons from Sweden 2003-2008. Energy Policy, 38, 1255-1271.

Berman, S. L., Wicks, A. C., Kotha, S., Jones, T. M., 1999. Does stakeholder orientation matter? The relationship between stakeholder management models and firm performance. Academy of Management Journal, 42, 488-506.

Bernicchi and King, 2007. Postcards from the Edge. A Review of the Business and Environment, in: Walsh, J.P., Brief, A.P., 2007. The Academy of Management Annals, Lawrence Erlbaum Associates, New York.

Carrión-Flores, C.E., Innes, R., 2010. Environmental innovation and environmental performance. Journal of Environmental Economics and Management, 59, $27-42$.

Clarkson, P. M., Li, Y., Richardson, G. D., Vasvari, F. P., 2011. Does it really pay to be green? Determinants and consequences of proactive environmental strategies. Journal of Accounting and Public Policy, 30, 122-144.

Cohen, M. A., Fenn, S. A., Konar, S., 1997. Environmental and financial performance: Are they related? Working paper, Vanderbilt University, Nashville.

Cordeiro, J. J., Sarkis, J., 1997. Environmental proactivism and firm performance: Evidence from security analyst earnings forecasts. Business Strategy and the Environment, 6, 104-114.

Delmas, M., Nairn-Birch, N., 2010. Is the Tail Wagging the Dog: An Empirical Analysis of Corporate Carbon Footprint and Financial Performance. UCLA Environmental Science and Engineering, Working Paper 6. 
Dixon-Fowler, H., Slater, D.J., Johnson, J.L., Ellstrand, A.E., Romi, A.M., 2012. Beyond “'Does it Pay to be Green?' A Meta-Analysis of Moderators of the CEP-CFP Relationship. Journal of Business Ethics, 112, 353-366.

Dooley, R. S., Fryxell, G. E., 1999. Are conglomerates less environmentally responsible? An empirical examination of diversification strategy and subsidiary pollution in the U.S. chemical industry. Journal of Business Ethics, 21, 1-14.

Dowell, G., Hart, S., Yeung, B., 2000. Do corporate global environmental standards create or destroy market value. Management Science, 46, 1059-1074.

Earnhart, D., Lizal, L., 2006. Effects of ownership and financial performance on corporate environmental performance. Journal of Comparative Economics, 34, 111-129.

Earnhart, D., Lízal, L., 2007. Effect of Pollution Control on Corporate Financial Performance in a Transition Economy. European Environment 17, 247-266.

Elsayed, K., Paton, D., 2005. The impact of environmental performance on firm performance: static and dynamic panel data evidence. Structural Change and Economic Dynamics, 16, $395-412$.

Energy Intelligence, 2014. EI New Energy Top 100 Green Utilities. Available at: http://www.qualenergia.it/sites/default/files/articolo-doc/Green_Utilities_Supplement.pdf (Accessed on 10 October 2015).

Ernst \& Young, 2013. Benchmarking European power and utility asset impairments. Available at:http://www.ey.com/Publication/vwLUAssets/EY_Benchmarking_European_power_and_ utility_asset_impairments_2014/\$FILE/EY-Benchmarking-European-power-and-utilityasset-impairments-2014.pdf (Accessed 12 June 2016). 
Filbeck, G., Gorman, R.F., 2004. The Relationship between the Environmental and Financial Performance of Public Utilities. Environmental and Resource Economics, 29, 137-157.

Frankfurt School-UNEP Centre/BNEF, 2015. Global trends in renewable energy investment 2015. Available at: http://fs-unep-centre.org/publications/global-trends-renewableenergy-investment-2015 (Accessed 10 March 2016).

Gallego-Álvarez, I., García-Sánchez, I.M., da Silva Vieira, C., 2014. Climate Change and Financial Performance in Times of Crisis. Business Strategy and the Environment, 23, 361374.

Gilley, K. M., Worrel, D. L., El Jelly, A., 2000. Corporate environmental initiatives and anticipated firm performance: The differential effects of process-driven versus productdriven greening initiatives. Journal of Management, 26, 1199-1216.

Graves, S. B., Waddock, S. A., 1999. A look at the financial-social performance nexus when quality of management is held constant. International Journal of Value-Based Management, $12,87-99$.

Guenster, N., Derwall, J., Bauer, R., Koedijk, K., 2005. The economic value of corporate ecoefficiency. Paper presented at the annual Academy of Management conference, Honolulu, HI.

Gupta, A., Smith, K., Shalley, C., 2006. The Interplay between Exploration and Exploitation. The Academy of Management Journal, 49(4), 693-706.

Hart, S.L., 1995. A Natural-Resource-Based View of the Firm. Academy of Management Review, 20, 986-1014.

Hart, S.L., 1997. Beyond greening: Strategies for a sustainable world. Harvard Business Review, $75,66-76$. 
Hart, S.L., 2007. Capitalism at the Crossoads: Aligning Business, Earth, and Humanity. Pearson Prentice Hall, Upper Saddle River.

Hart, S.L., Ahuja, G., 1996. Does it pay to be green? An empirical examination of the relationship between emission reduction and firm performance. Business Strategy and the Environment, 5, 30-37.

Hart, S.L., Dowell, G., 2011. A natural-resource-based view of the firm: 15 years after. Journal of Management, 37, 1464-1479.

Hassel, L., Nilsson, H., Nyquist, S., 2005. The value relevance of environmental performance. European Accounting Review, 14, 41-61.

Haveman, R., Christiansen, G., 1981. Environmental regulations and productivity growth, in: H. Peskin, P. Portney, A. Kneese, eds. Environmental Regulation and the U.S. Economy. Resources for the Future, Washington, DC.

Hughes, S. B., Anderson, A., Golden, S., 2001. Corporate environmental disclosures: Are they useful in determining environmental performance? Journal of Accounting and Public Policy, 20, 217-240.

IEA, 2015. CO2 emissions from fuel combustion, Highlights. Available at: https://www.iea.org/publications/freepublications/publication/CO2EmissionsFromFuelCom bustionHighlights2015.pdf (Accessed 26 April 2016).

IEA, 2016. World Energy Outlook 2016 (To be released on 16 November 2016). Available at: http://www.worldenergyoutlook.org/publications/weo-2016/ (Accessed on 16 March 2016).

IEA/IRENA, 2016. Global Renewable Energy Policies and Measures Database. Available at: https://www.iea.org/policiesandmeasures/renewableenergy/ (Accessed September 2016) 
Ilinitch, A. Y., Soderstrom, N. S., Thomas, T. E., 1998. Measuring corporate environmental performance. Journal of Accounting and Public Policy, 17, 383-408.

Jaggi, B., Freedman, M., 1992. An examination of the impact of pollution performance on economic and market performance: pulp and paper firms. Journal of Business Finance \& Accounting, 19, 697-713.

Jung, E. J., Kim, J. S., Rhee, S. K., 2001. The measurement of corporate environmental performance and its application to the analysis of efficiency in oil industry. Journal of Cleaner Production, 9, 551-563.

Karagozoglu, N., Lindell, M., 2000. Environmental Management: Testing the Win-Win Model. Journal of Environmental Planning and Management, 43, 817-829.

Khanna, M., Quimio, W. R., Bojilova, D., 1998. Toxic release information: A policy tool for environmental protection. Journal of Environmental Economics and Management, 36, 243266.

King, A.A., Lenox, M.J., 2001. Does It Really Pay to Be Green? An Empirical Study of Firm Environmental and Financial Performance: An Empirical Study of Firm Environmental and Financial Performance. Journal of Industrial Ecology, 5, 105-116.

Konar, S., Cohen, M. A., 2001. Does the market value environmental performance? Review of Economics and Statistics, 83, 281-289.

Levy, D.L., 1995. The environmental practices and performance of transnational corporation. Transnational Corporations, 4, 44-67.

Lindenberg, E. B., Ross, S. A., 1981. Tobin's q Ratio and Industrial Organization. The Journal of Business, 54(1), 1-32. 
Magness, V., 2006. Strategic posture, financial performance and environmental disclosure: An empirical test of legitimacy theory. Accounting, Auditing \& Accountability Journal, 19, $540-563$.

Makni, R., Francoeur, C., Bellavance, F., 2009. Causality between corporate social performance and financial performance: Evidence from Canadian firms. Journal of Business Ethics, 89, $409-422$.

March, J., 1991. Exploration and Exploitation in Organizational Learning. Organization Science, 2(1), 71-87.

Martin, S., 1993. Advanced Industrial Economics. Blackwell Publishers. Oxford.

McGuire, J. B., Sundgren, A., Schneeweis, T., 1988. Corporate social responsibility and firm financial performance. Academy of Management Journal, 31, 854-872.

McWilliams, A., Siegel, D., 2000. Corporate social responsibility and financial performance: Correlation or misspecification? Strategic Management Journal, 21, 603-609.

Menanteau, P., Finon, D., Lamy, M., 2003. Prices versus quantities: choosing policies for promoting the development of renewable energy. Energy Policy, 31, 799-812.

Miller, D., Friesen, P. H., 1983. Strategy-making and environment: The third link. Strategic Management Journal, 4, 221-235.

Moody's, 2012. Wind and solar power will continue to erode thermal generators' credit quality. Available at: https://www.moodys.com/research/Moodys-Wind-and-solar-power-willcontinue-to-erode-thermal_PR_259122 (Accessed 10 June 2016). 
Morris, S. A., 1997. Environmental pollution and competitive advantage: An exploratory study of U. S. industrial-goods manufacturers. Academy of Management Best Papers Proceedings, 411-415.

Nishitani, K., Kokubu, K., 2012. Why Does the Reduction of Greenhouse Gas Emissions Enhance Firm Value? The Case of Japanese Manufacturing Firms. Business Strategy and the Environment, 21, 517-529.

Orlitzky, M., Schmidt, F.L., Rynes, S.L., 2003. Corporate Social and Financial Performance: A Meta-Analysis. Organization Studies, 24, 403-441.

Orsato, J., 2009. Sustainable Strategies: When Does It Pay To Be Green? Journal of Industrial Ecology, 16, 450-450.

Palmer, K., Oates, W. E., Portney, P. R., 1995. Tightening environmental standards: The benefit-cost or the no-cost paradigm? Journal of Economic Perspectives, 9, 119-132.

Pätäri, S., Arminen, H., Tuppura, A., Jantunen, A., 2014. Competitive and responsible? The relationship between corporate social and financial performance in the energy sector. Renewable and Sustainable Energy Reviews, 37, 142-154.

Porter, M.E., van, d.L., 1995. Green and Competitive: Ending the Stalemate. Harvard business review, 73, 120-134.

Portney, P., 1994. Does environmental policy conflict with economic growth? Resources, Spring, 21-23.

Raisch S., Birkinshaw J., Probst G., Tushman M. L., 2009. Organizational ambidexterity: balancing exploitation and exploration for sustained performance, Organization Science 20, 685-69. 
REN21, 2016. Publications. Available at: http://www.ren21.net/resources/publications/. (Accessed 12 September 2016).

Reinhardt, F., 1999. Market Failure and the Environmental Policies of Firms: Economic Rationales for ?Beyond Compliance? Behavior. Journal of Industrial Ecology, 3, 9-21.

Richter, M., 2012. Utilities' business models for renewable energy: A review. Renewable and Sustainable Energy Reviews, 16, 2483-2493.

Ruggiero, S., Varho, V., Rikkonen, P., 2015. Transition to distributed energy generation in Finland: Prospects and barriers. Energy Policy, 86, 433-443.

Russo, M. V., Fouts, P. A., 1997. A resource-based perspective on corporate environmental performance and profitability. Academy of Management Journal, 40, 534-559.

Sen, P., Roy, M., Pal, P., 2015. Exploring role of environmental proactivity in financial performance of manufacturing enterprises: a structural modelling approach. Journal of Cleaner Production, 108, Part A, 583-594.

Stenzel, T., Frenzel, A., 2008. Regulating technological change-The strategic reactions of utility companies towards subsidy policies in the German, Spanish and UK electricity markets. Energy Policy, 36, 2645-2657.

Stoeckl, N., 2004. The private costs and benefits of environmental self-regulation: which firms have most to gain? Business Strategy and the Environment, 13, 135-155.

Sueyoshi, T., Goto, M., 2009. Can environmental investment and expenditure enhance financial performance of US electric utility firms under the clean air act amendment of 1990? Energy Policy, 37, 4819-4826. 
Surroca, J., Tribó, J. A., Waddock, S., 2010. Corporate responsibility and financial performance: The role of intangible resources. Strategic Management Journal, 31, 463-490.

Telle, K., 2006. 'It pays to be green' - A premature conclusion? Environmental and Resource Economics, 35, 195-220.

The Economist, 2013. How to lose half a trillion euros. Ayailable at: http://www.economist.com/news/briefing/21587782-europes-electricity-providers-faceexistential-threat-how-lose-half-trillion-euros (Accessed 21 February 2016).

Thomson Reuters, (2016). Worldscope Information. Available at: http://extranet.datastream.com/Data/Worldscope/index.htm (Accessed 9 February 2016).

UN, 2016. Global investors mobilize action in wake of Paris Climate Agreement. Available at: http://www.un.org/sustainabledevelopment/blog/2016/01/global-investors-mobilizeaction-in-wake-of-paris-climate-agreement/ (Accessed 12 March 2016).

Verbeek, M., 2008. A Guide to Modern Econometrics. John Wiley \& Sons Ltd, West Sussex, England.

Verbruggen, A., Lauber, V., 2012. Assessing the performance of renewable electricity support instruments. Energy Policy, 45, 635-644.

Waddock, S. A., Graves, S. B., 1997. The corporate social performance-financial performance link. Strategic Management Journal, 18, 303-319.

Wagner, M., Schaltegger, S., 2004. The effect of environmental strategy choice and environmental performance on competitiveness and economic performance: An empirical study of EU manufacturing. European Journal of Management, 22, 557-572.

Walley, N., Whitehead, B., 1994. It's not easy being green. Harvard Business Review 72, 3, $2-7$. 
Wang, L., Li, S., Gao, S., 2014. Do Greenhouse Gas Emissions Affect Financial Performance? An Empirical Examination of Australian Public Firms. Business Strategy and the Environment, 23, 505-519.

Whitehead, B., 1994. It's not easy being green. Harvard Business Review 72, 3, 2-7.

Zeng, S.X., Meng, X.H., Yin, H.T., Tam, C.M., Sun, L., 2010. Impact of cleaner production on business performance. Journal of Cleaner Production, 18, 975-983. 


\section{Highlights}

- Panel data covering a 10-year period for 66 large electric utilities is analyzed.

- A negative correlation between renewable energy and financial performance is found.

- A firm's carbon intensity acts as a moderator.

- Renewable energy Granger-causes a negative change in firms' long-term financial performance. 